\title{
Evaluation of a dehumidifier in a mild weather greenhouse
}

\author{
José-María Cámara-Zapata ${ }^{\mathrm{a},}$, Jorge-Antonio Sánchez-Molina ${ }^{\mathrm{b}}$, Francisco Rodríguez ${ }^{\mathrm{b}}$, Juan- \\ Carlos López ${ }^{\mathrm{c}}$
aDepartment of Physics and Computer Architecture, University Miguel Hernandez, Avda. Universidad, s/n, 03202 Elche, Spain (jm.camara@umh.es)
bDepartment of Informatics, University of Almeria, Carretera Sacramento s/n, 04120 Almería, Spain. CeiA3.
CIESOL (jorgesanchez@ual.es; frrodrig@ual.es)
'Experimental Station of Cajamar Foundation "Las Palmerillas", 04710 El Ejido, Almeria, Spain
(juancarloslopez@fundacioncajamar.com)
*Corresponding author: José-María Cámara-Zapata (jm.camara@umh.es)

\begin{abstract}
The high humidity surrounding crop plants, aggravated in mild weather greenhouses by high transpiration and lack of ventilation, favours plant diseases and physiological disorders. A heat pump dehumidifier (HPD) has been installed in a mild weather greenhouse. Its development and the characteristics of the dehumidification process have been studied. The results indicate that the HPD reduced the risk of crop damage due to the humidity. The efficiency was related to the value of the temperature and humidity of the air inside the greenhouse. The operation of HPD was not adequated whith dry weather. On the other hand, when humidity was excessive, the effect of HPD on the risk of moisture damage was not sufficient. Optimal conditions to eliminate the risk of humidity damage through the use of an HPD are the relative humidity between $84 \%$ and $88 \%$, and the air temperature higher than $15.0{ }^{\circ} \mathrm{C}$. Under these conditions, the value of the condensed steam production was $14.2 \mathrm{~kg} \mathrm{~h}^{-1}$, the specific moisture extraction rate was $2.3 \mathrm{~kg}\left(\mathrm{~kW} \mathrm{~h}^{-1}\right)$, and the coefficient of performance was 2.5 .
\end{abstract}

\section{Keywords}

High humidity; plant diseases; heat pum; mass and energy conservation 


\section{Introduction}

In the horticultural sector of mild weather areas, most greenhouses are very simple constructions covered with a plastic film and without active climate-control systems $[1,2,3]$. Environmental control is essentially achieved using ventilation techniques to control temperature $(T)$ and humidity, which are - in most cases - far from ideal and strongly dependent on the outside conditions, resulting in relatively low yields [4]. Relative humidity $(R H)$ tends to be high due to crop transpiration and low $T$, especially during the autumn-winter period [2]. Hand [5] showed that for a vapour pressure deficit $(V P D)$ lower than $0.20 \mathrm{kPa}$, plant diseases are favoured and physiological disorders may occur. Nowadays, low-energy-demand, closed greenhouses are used to increase crop production by increasing the control over other variables like $\mathrm{CO}_{2}$ or $T$ - and are aimed at sustainable crop production, but induce higher humidity levels $[5,6,7]$. In order to improve growing conditions and prevent the emergence of crop diseases, it is necessary to reduce the effects of low $T$ and high humidity inside the greenhouse $[8,9]$.

A proper dehumidification method must prevent the risk of humidity damage [10] and maintaining the greenhouse sealed, to get a homogeneous climate and high levels of $\mathrm{CO}_{2}$ when enrichment systems are installed. The method used most commonly to avoid moisture damages combines ventilation and heating [11]. Despite its low energy efficiency, this method is widely used because it only requires ventilation and heating systems $[12,13]$. The use of vapour compression cycles to control the humidity in greenhouses has been investigated $[14,15,16]$. The main advantages of this method with regard to this application are (i) the recovery of the latent heat of the condensed water vapour and its use in heating and (ii) the efficiency in the control of the humidity is independent of the conditions of the external air [17]. At present, there are numerous studies on other dehumidification technologies with great potential, such as desiccant-based or membrane-based systems, although it is still necessary to improve their designs to compete with the conventional vapour compression system [18-23]. The energy consumption of a heat pump dehumidifier (HPD) can be significantly lower than that of systems with ventilation and heating, depending on the climate inside the greenhouse [14]. In cold 
regions, dehumidification systems are effective in controlling humidity throughout the year $[16$, 22]. However, it is not known if the use of HPDs can be effective to reduce the humidity in mild weather greenhouses.

The objective of this work was to evaluate the performance of an HPD with regard to reducing the risk of humidity damage in a mild weather greenhouse. An extensive series of dehumidification assays has been performed. The results shown that it is possible to eliminate the risk of humidity damage through the use of the HPD. This analysis makes possible to optimise the performance of the HPD. The efficiency of HPD is a function of climate. The optimal functioning of HPD is achieved with intermediate temperature and high humidity. The efficiency gets worse if the temperature and humidity are low. In a greenhouse, the humidity is usually high due to transpiration and lack of ventilation. Therefore, it is possible to reduce the risk of moisture damage in greenhouse crops by using an HPD with optimal performance. It is necessary to continue research to determine its energy consumption and its effect on the use of fungicides and on the quality and production of the crop.

\section{Material and methods}

\subsection{Greenhouse facilities}

The data used in this research were acquired from the Cajamar Foundation Experimental Station

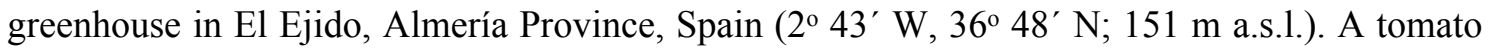
crop was grown in a multispan Parral-type greenhouse with an area of $877 \mathrm{~m}^{2}$ (Figs. 1a and 1d). The roof runs from East to West, and the crop rows are aligned North-South. It has automated ventilation by means of windows in the North and South walls, flap roof windows in each span, a heating system with an aerothermal generator of $95 \mathrm{~kW}$ (Ernaf RGA95) and a heat pump dehumifier (HPD, FRAL FD980, Fig. 1b). The growing conditions and crop management were very similar to those in commercial greenhouses. The crops were grown in $40-\mathrm{L}$ coconut coir slabs, placed in gutters with a $1 \%$ longitudinal slope and with a crop density of 2.0 plants $\mathrm{m}^{-2}$. 


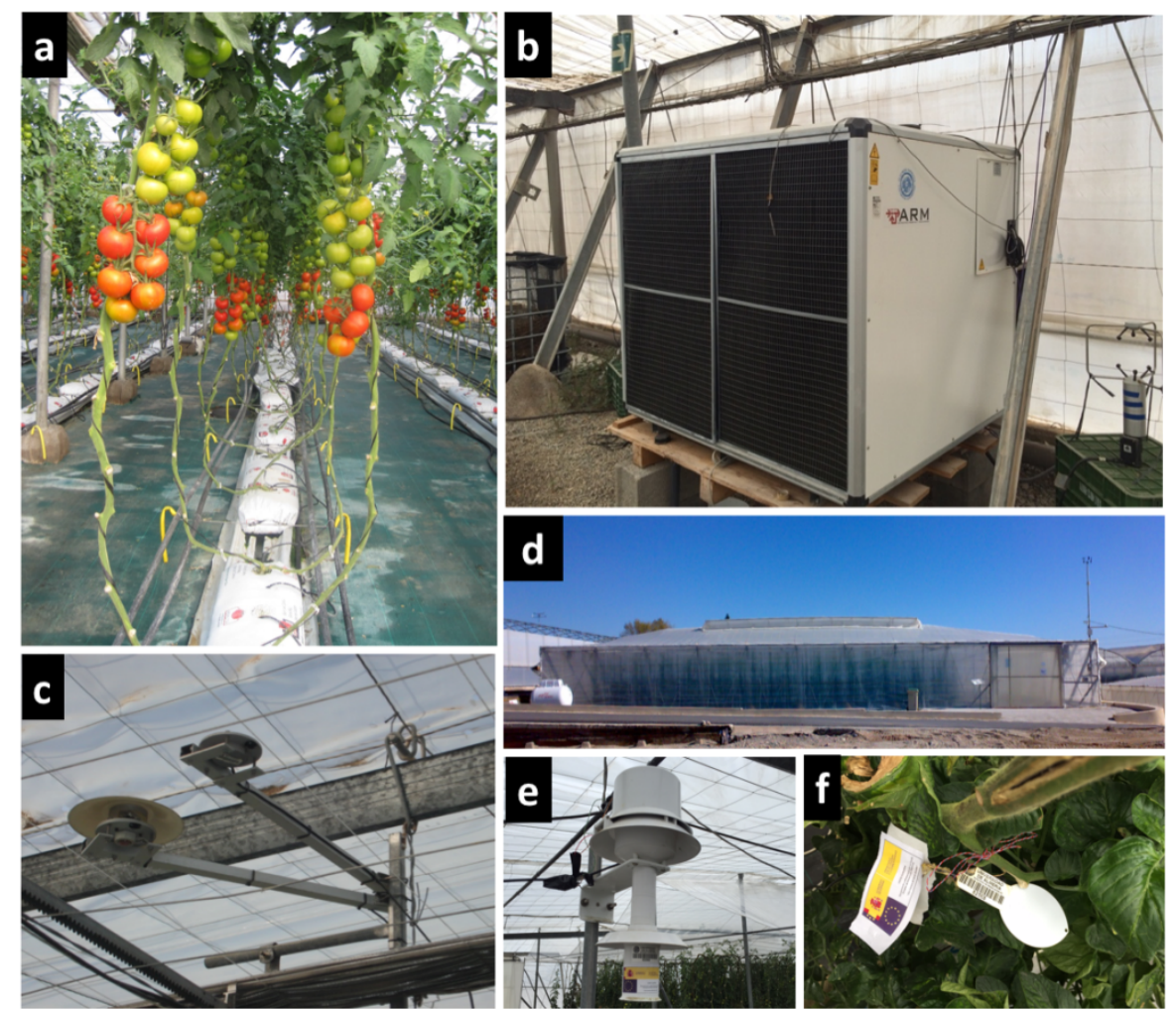

Fig. 1. Greenhouse facilities used for the experiments performed in this work: a. tomato plants, $b$. heat pump dehumidifier (HPD), c. radiation sensors d. multispan greenhouse, e. temperature and humidity sensors, and f. leaf condensation sensor.

Throughout the crop season, several internal and external parameters were continuously monitored (Fig. 2). Outside the greenhouse, a weather station measured, among others variables, air temperature $(T)$ and relative humidity $(R H)$ with a ventilated sensor (Vaisala HMP45P). Inside the greenhouse, were recorded solar radiation with a pyranometer (Delta-Ohm LP PYRA 03, Fig. 1c), air $T$ and $R H$ (Vaisala HMP45P, Fig. 1e) and power $(P)$ consumption (Sineax m563). The data were collected every $30 \mathrm{~s}$.

Fig. 3 shows a scheme of the HPD components and the probes used in the experiments. The $\mathrm{R} 407 \mathrm{C}$ refrigerant was used. The compressor has the highest energy consumption in a device with a theoretical maximum consumption of $12.0 \mathrm{~kW}$ and 32.0 A. A Scroll-type compressor was used. The HPDs defrost during the periodic stopping of the compressor, using the heat of the environment itself. The $T$ and $R H$ at the inlet to the HPD, the outer surface temperature of the evaporator, the $T$ of the air at the outlet of the HPD and the mass of condensed water vapour were measured. 


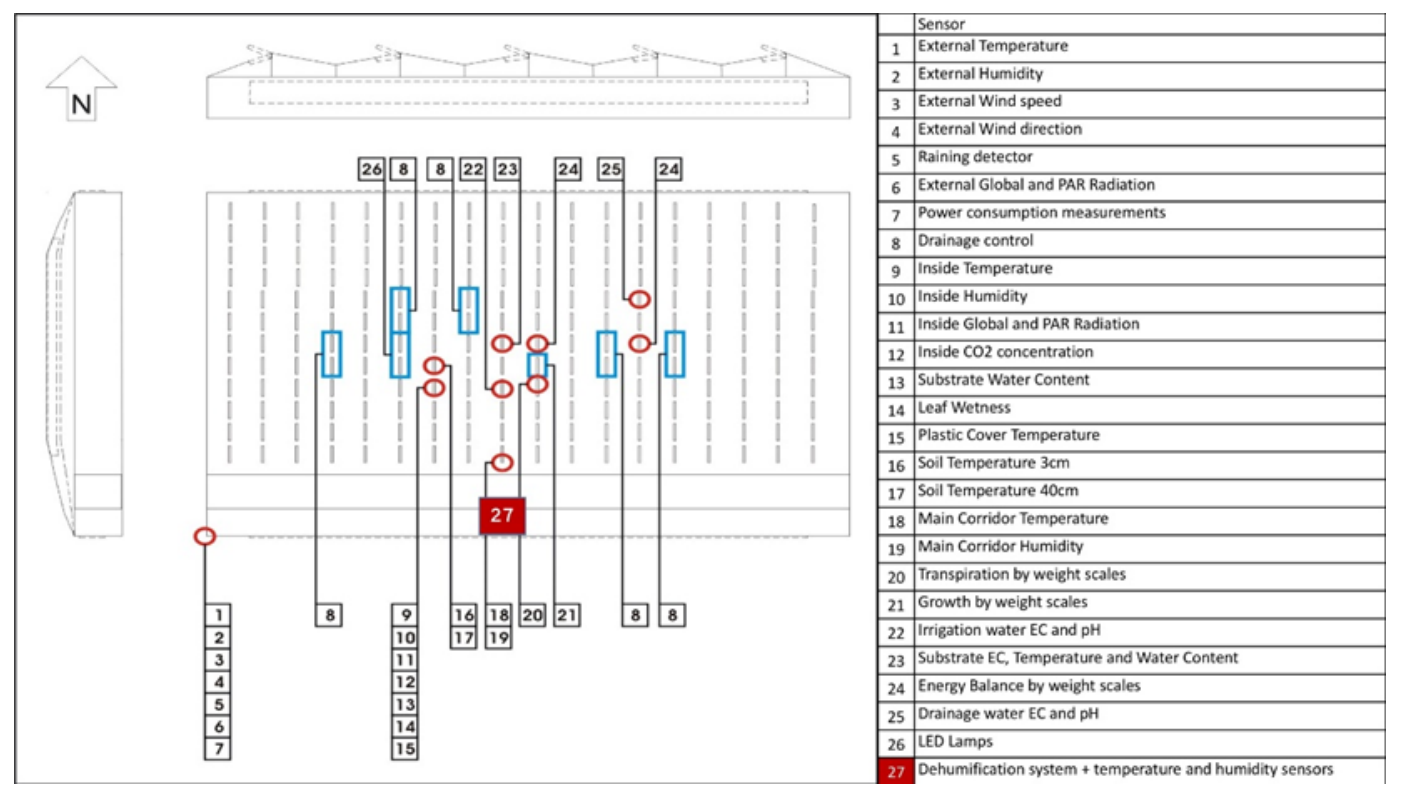

Fig. 2. Relationship and distribution of sensors in the greenhouse.

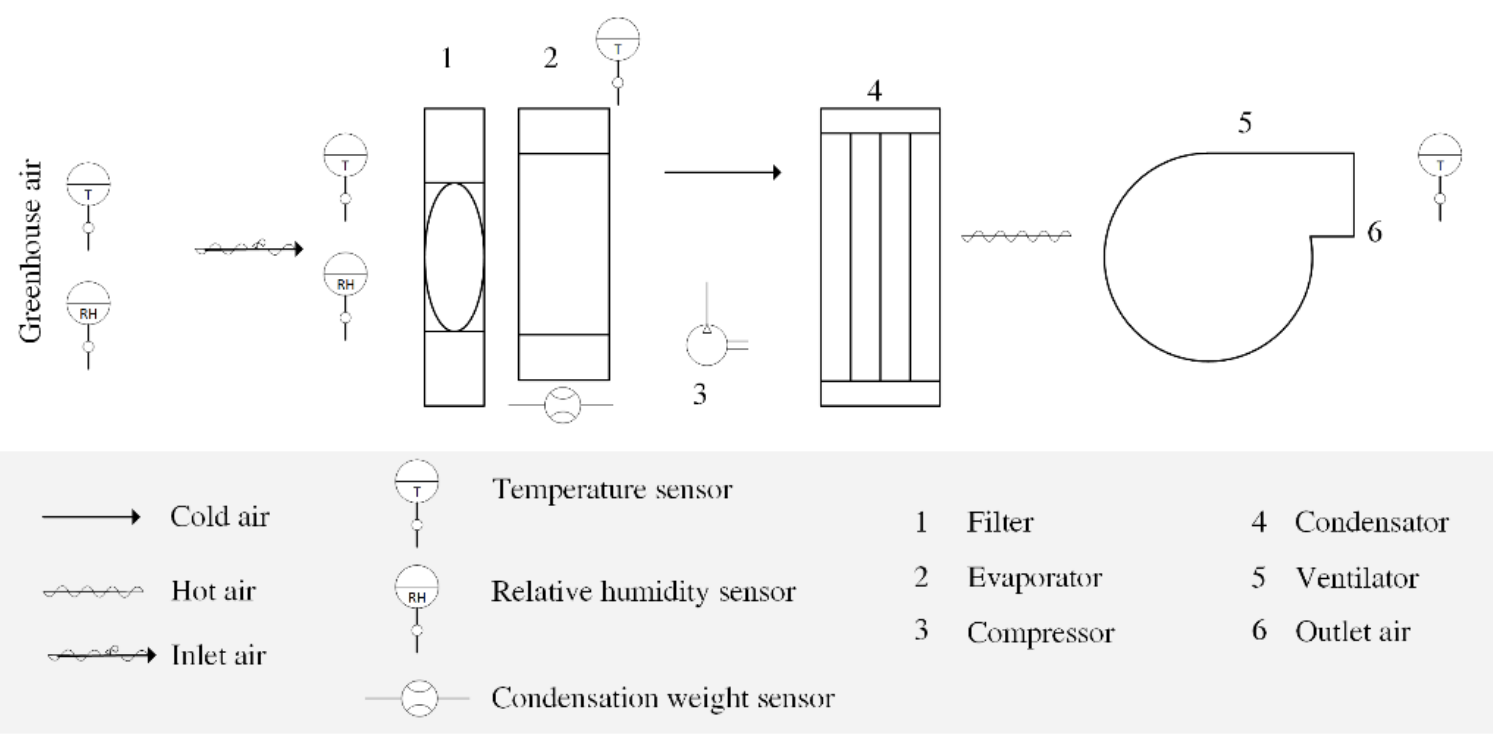

Fig. 3. The refrigeration-based dehumidifier scheme

\subsection{Parameters of functioning of HPD}

The mass of condensed water vapour in the HPD over a time interval, $M C V(\mathrm{~kg})$, was determined from matter and energy balances of the air in the greenhouse, as follows (see Appendix): 
Where $W_{\mathrm{d}}(\mathrm{J})$ is the energy transferred from the HPD, and $h_{\mathrm{w}, \mathrm{d}}$ and $h_{\mathrm{w}, \mathrm{n}}\left(\mathrm{J} \mathrm{kg}^{-1}\right)$ represent the enthalpy of condensed water by the action of the HPD and naturally in the greenhouse - both establish the $T$ of the surface of the evaporator and the dew point of the air - respectively [24]. The mass of air treated in the HPD, MAT (kg), was obtained from an air mass balance in the evaporator and combinating the energy balances of the air in the evaporator and in the condenser [25]:

$$
M A T=M C V\left(\left(h_{\mathrm{w}, \mathrm{n}}+h_{\mathrm{vf}}-2 h_{\mathrm{w}, \mathrm{d}}\right) /\left(h_{\mathrm{af}}-h_{\mathrm{ai}}+\omega_{\mathrm{i}}\left(h_{\mathrm{vf}}-h_{\mathrm{vi}}\right)\right)\right.
$$

Where $h_{\mathrm{a}}\left(\mathrm{J} \mathrm{kg}^{-1}\right)$ is the enthalpy of dry air, $h_{\mathrm{v}}\left(\mathrm{J} \mathrm{kg}^{-1}\right)$ is the enthalpy of steam, and $\omega\left(\mathrm{kg} \mathrm{kg}^{-1}\right)$ is the specific humidity. Subscripts $i$ and $f$ refer to the initial and final state of the air in the HPD, respectively. In all of the calculation, the disconexion time for defrosting has been taken into account. The latent heat $\left(Q_{1, \mathrm{~d}}, \mathrm{~J}\right)$ exchanged by the air passing through the HPD are determined as:

$$
Q_{1, \mathrm{~d}}=\operatorname{MAT}\left(\omega_{\mathrm{f}} L_{\mathrm{f}}-\omega_{\mathrm{i}} L_{\mathrm{i}}\right)
$$

Where $L\left(\mathrm{~J} \mathrm{~kg}^{-1}\right)$ is the latent heat of water vapour. The specific moisture extraction rate, SMER $\left(\mathrm{kg}(\mathrm{kW} \mathrm{h})^{-1}\right)$, was determined as the ratio of the mass of condensed water vapour, $M C V(\mathrm{~kg})$, and energy consumed, $W_{\mathrm{d}}(\mathrm{kW} \mathrm{h})$.

$$
S M E R=M C V / W_{\mathrm{d}}
$$

The drying efficiency of an HPD can be expressed as its coefficient of performance $(C O P)$; that is, a measure of the quantity of energy used in removing a unit mass of water. It was obtained according to $[26]$

$$
C O P=1+S M E R \cdot L
$$




\section{Results and discussion}

\subsection{Effect of the HPD on the risk of humidity damage}

A total of 35 dehumidification processes were carried out over 25 days at different times of day in autumn and winter, when the risk of humidity damage is greater. (Table 1). The duration of the experiments ranged from 2 to 3 hours, with the HPD operating for about 85 hours, yielding more than 10,000 values of each of the measured parameters. The operation of the HPD was distributed approximately as follows: $45 \%$ between 06:00 and 12:00 (midday), 10\% between 12:00 and 18:00, 30\% between 18:00 and $24: 00$ and $15 \%$ between $00: 00$ and 06:00.

\begin{tabular}{|c|c|c|c|c|c|c|c|c|c|c|c|c|c|c|c|c|c|c|c|c|c|c|c|c|}
\hline & \multicolumn{24}{|c|}{ Time (h) } \\
\hline Date & 1 & 2 & 3 & 4 & 5 & 6 & 7 & 8 & 9 & 10 & 11 & 12 & 13 & 14 & 15 & 16 & 17 & 18 & 19 & 20 & 21 & 22 & 23 & 24 \\
\hline 9-D & & & & & & & & & & & & & & & & & & & & & & & & \\
\hline $11-\mathrm{D}$ & & & & & & & & & & & & & & & & & & & & & & & & \\
\hline $12-\mathrm{D}$ & & & & & & & & & & & & & & & & & & & & & & & & \\
\hline $13-\mathrm{D}$ & & & & & & & & & & & & & & & & & & & & & & & & \\
\hline 14-D & & & & & & & & & & & & & & & & & & & & & & & & \\
\hline $15-\mathrm{D}$ & & & & & & & & & & & & & & & & & & & & & & & & \\
\hline $16-\mathrm{D}$ & & & & & & & & & & & & & & & & & & & & & & & & \\
\hline 17-D & & & & & & & & & & & & & & & & & & & & & & & & \\
\hline $18-\mathrm{D}$ & & & & & & & & & & & & & & & & & & & & & & & & \\
\hline 19-D & & & & & & & & & & & & & & & & & & & & & & & & \\
\hline 20-D & & & & & & & & & & & & & & & & & & & & & & & & \\
\hline 29-D & & & & & & & & & & & & & & & & & & & & & & & & \\
\hline $30-\mathrm{D}$ & & & & & & & & & & & & & & & & & & & & & & & & \\
\hline $3-\mathrm{F}$ & & & & & & & & & & & & & & & & & & & & & & & & \\
\hline $5-\mathrm{F}$ & & & & & & & & & & & & & & & & & & & & & & & & \\
\hline 6-F & & & & & & & & & & & & & & & & & & & & & & & & \\
\hline $7-\mathrm{F}$ & & & & & & & & & & & & & & & & & & & & & & & & \\
\hline 8-F & & & & & & & & & & & & & & & & & & & & & & & & \\
\hline $13-\mathrm{F}$ & & & & & & & & & & & & & & & & & & & & & & & & \\
\hline $15-\mathrm{F}$ & & & & & & & & & & & & & & & & & & & & & & & & \\
\hline $23-\mathrm{F}$ & & & & & & & & & & & & & & & & & & & & & & & & \\
\hline $25-\mathrm{F}$ & & & & & & & & & & & & & & & & & & & & & & & & \\
\hline $26-\mathrm{F}$ & & & & & & & & & & & & & & & & & & & & & & & & \\
\hline $27-\mathrm{F}$ & & & & & & & & & & & & & & & & & & & & & & & & \\
\hline $2-\mathrm{M}$ & & & & & & & & & & & & & & & & & & & & & & & & \\
\hline
\end{tabular}

It was assumed that HPD dehumidification eliminates the risk of moisture damage to the tomato crop when a value of $V P D \geq 0.20 \mathrm{kPa}$ is achieved [5, 13, 17, 27]. Therefore, Table 2 shows the results of the treatments according to the average value of $V P D$. The results of five processes in which the average temperature $(T)$ is higher than $20.0^{\circ} \mathrm{C}$ and the average relative humidity $(R H)$ is less than $70 \%$ are not presented. Under these conditions it is not necessary to perform dehumidification. However, these experiences have been scheduled because the objective of this 
study was not to eliminate the risk of moisture damage, but to evaluate the operation of HPD in a mild wheather greenhouse.

\begin{tabular}{|c|cc|ccc|}
\hline \multicolumn{3}{|c|}{ No risk of moisture damage } & \multicolumn{3}{c|}{ With risk of moisture damage } \\
\hline$T_{\text {med }}\left({ }^{\circ} \mathrm{C}\right)$ & $R H_{\text {med }}(\%)$ & $V P D_{\text {med }}(\mathrm{kPa})$ & $T_{\text {med }}\left({ }^{\circ} \mathrm{C}\right)$ & $R H_{\text {med }}(\%)$ & $V P D_{\text {med }}(\mathrm{kPa})$ \\
\hline 12.2 & 85 & 0.21 & 14.4 & 100 & 0.00 \\
10.9 & 84 & 0.22 & 11.0 & 97 & 0.05 \\
14.5 & 86 & 0.23 & 11.3 & 95 & 0.08 \\
14.6 & 88 & 0.24 & 13.1 & 94 & 0.09 \\
15.0 & 85 & 0.26 & 12.5 & 93 & 0.10 \\
17.3 & 88 & 0.28 & 11.6 & 93 & 0.10 \\
9.9 & 75 & 0.31 & 12.2 & 92 & 0.11 \\
18.7 & 88 & 0.31 & 12.3 & 91 & 0.13 \\
12.0 & 76 & 0.34 & 11.3 & 90 & 0.13 \\
9.9 & 72 & 0.35 & 11.1 & 88 & 0.15 \\
18.5 & 86 & 0.39 & 13.8 & 89 & 0.17 \\
11.9 & 72 & 0.40 & 14.1 & 90 & 0.17 \\
15.5 & 69 & 0.56 & 18.0 & 93 & 0.17 \\
17.2 & 69 & 0.61 & 12.4 & 87 & 0.19 \\
18.1 & 67 & 0.70 & 19.5 & 92 & 0.19 \\
\hline
\end{tabular}

Table 2. Mean values of the $T\left({ }^{\circ} \mathrm{C}\right), \mathrm{RH}(\%)$ and $V P D(\mathrm{kPa})$ during dehumidification processes.

The effect of dehumidification on the risk of humidity damage varies with the values of the $T$ and $R H$. The HPD was efficient with cold and dry weather but not with low $T$ and high $R H$. In general, dehumidification treatments were efficient when the average $R H$ was lower than $88 \%$.

\subsection{Dynamic behaviour of the air water-content}

The evolution of $T$ and $R H$ of the air in the greenhouse during two days of autumn (14 and 20 December) and two of winter (13 and 15 February) shows that, in general, the reductions in $R H$ and the mean value of $T$ were greatest in the assays carried out in autumn (Fig. 4). Thus, all the assays shown were effective, except for the night treatments in winter (the second of February 13 and the first of February 15). If the moisture increase, the effect of dehumidification can improve by increasing the value of $T$. 


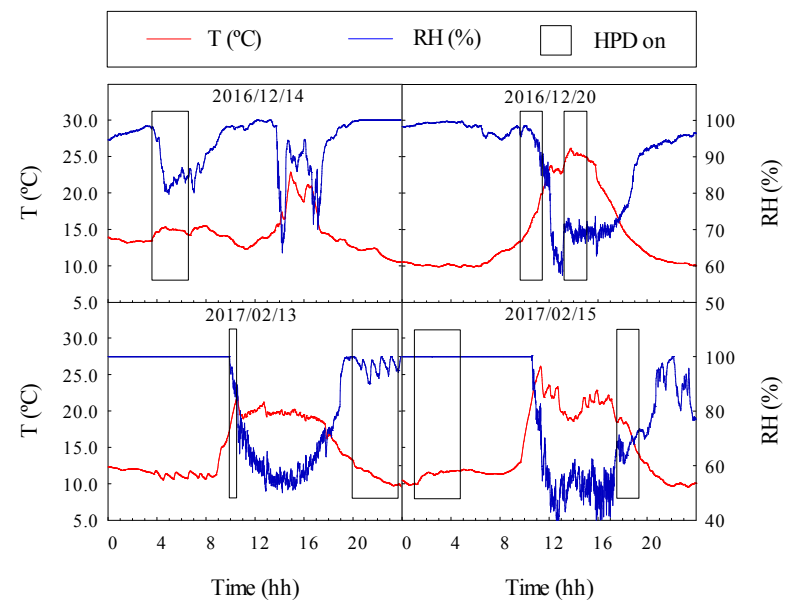

Fig. 4. Evolution of temperature $\left(T,{ }^{\circ} \mathrm{C}\right)$ and relative humidity $(\mathrm{RH}, \%)$ inside the greenhouse

Fig. 5 shows the evolution of the properties of the air and the development of the HPD (power consumption, $P, \mathrm{~kW}$; vapour condensation temperature, $T_{\mathrm{c}},{ }^{\circ} \mathrm{C}$; initial air temperature in the $\mathrm{HPD}, T_{\mathrm{i}},{ }^{\circ} \mathrm{C}$; and final air temperature in the HPD, $T_{\mathrm{f}},{ }^{\circ} \mathrm{C}$ ) at dawn (between 07:00 and 10:00) and at night (between 20:00 and 22:50) on 12 December.

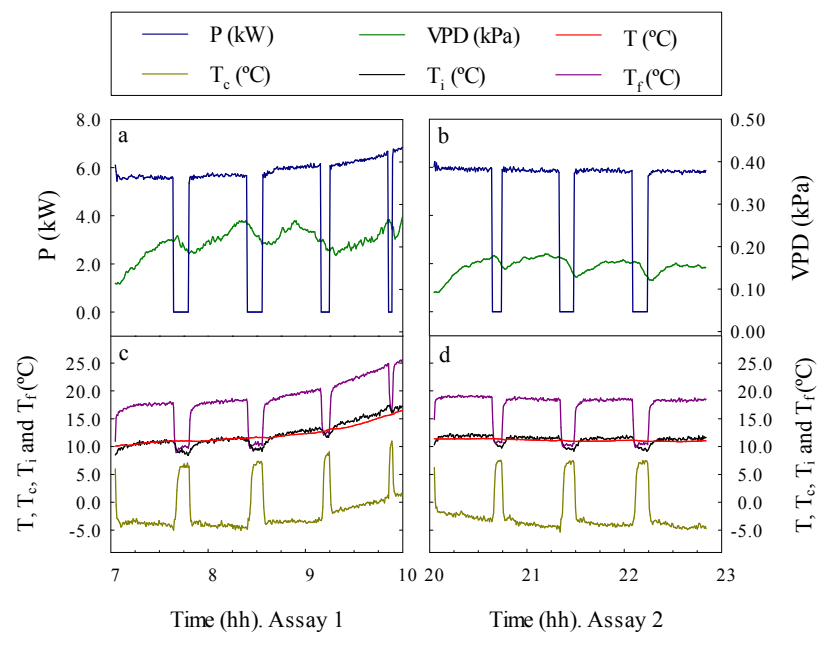

Fig. 5. Two dehumidification assays with differents results (2016/12/12)

The duration of the two assays and the inicital climate were very similar. However, only the morning dehumidification could avoid the risk of humidity damage $\left(V P D_{\text {med }}=0.21 \mathrm{kPa}\right.$; i.e., $\geq 0.20 \mathrm{kPa}$ ) (Fig. 5a). In the morning experiment, $T$ increased by $6.4{ }^{\circ} \mathrm{C}$ from its initial value, with a $T_{\text {med }}$ of $12.2{ }^{\circ} \mathrm{C}$, while during the night-time test, $T$ hardly changed $\left(T_{\text {med }}=11.1{ }^{\circ} \mathrm{C}\right)($ Fig. $5 b)$. This influenced the values of the $P, T_{\mathrm{c}}, T_{\mathrm{i}}$, and $T_{\mathrm{f}}$. In the experiment performed at dawn, the values of these variables increased with time and the duration of the defrosting decreased as the 
assay progressed (Fig. 5c). In contrast, in the night-time trial, the values of $P, T_{\mathrm{i}}$, and $T_{\mathrm{f}}$ hardly varied. In this case, $T_{\mathrm{c}}$ values tended to decrease, so the duration of the defrosting increased (Fig. 5d).

The presence of frost on the evaporator obstructs the passage of air and reduces the surface area in contact with air, consequently lowering the efficiency [28 and 29]. For this reason, HPDs have thawing systems. Standard versions, such as the one used in this work, defrost simply by stopping the compressor periodically, using ambient energy. The lower the $T_{\mathrm{c}}$ value, the longer the HPD disconnection time and the lower its effectiveness. In addition, warmer air can absorb more water vapour [21].

\subsection{Relationship between climate and production of condensed water vapour}

Fig. 6 shows the evolution of $T, R H$ and $V P D$ during four dehumidification assays performed in the first hours of the day in winter. In all cases, the air was initially saturated $(R H=100 \%)$ and the experiences started between 8:00 and 8:30 h. The experiment of 25 February 2016 was performed at the lowest $T$. The climate inside the greenhouse in the rest of the assays was quite similar.

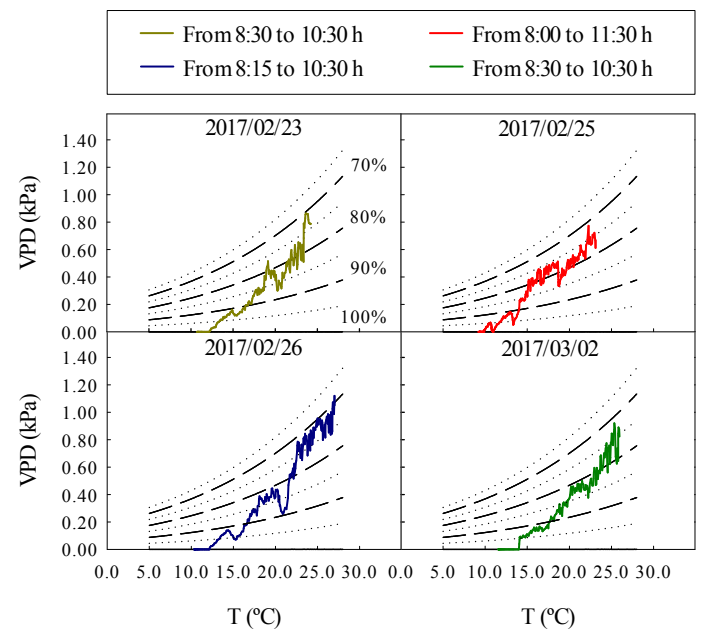

Fig. 6. Evolution of the values of $T\left({ }^{\circ} \mathrm{C}\right), \mathrm{RH}(\%)$ and $V P D(\mathrm{kPa})$ during the dehumidification assays

There were differences between the performance of the HPD and its reduction of the risk of humidity damage. In the assay of February 25 the condensed steam production $(C S P)$ was $20 \%$ lower than on 2 March although the HPD needed to operate for more than twice as long to 
reduce the risk of crop damage $\left(12.9 \mathrm{~kg} \mathrm{~h}^{-1}\right.$ and 104 min versus $17.6 \mathrm{~kg} \mathrm{~h}^{-1}$ and $49 \min$, respectively). The results of February 23 and 26 were similar to those of March 2.

The behaviour of the HPD is related with the external weather. Thereby, the cold and dry outside weather $\left(T_{\mathrm{med}}=13.3{ }^{\circ} \mathrm{C}\right.$ and $\left.R H_{\mathrm{med}}=25 \%\right)$ could explain the poor efficacy of the HPD on 25 February. The effect of dehumidification seem more favorable after the assay of 26 February, probably due to the longer duration of this assay (Fig. 6). However, the explanation may also lie in the humidity of the outside air during the assay $\left(R H_{\text {med }}=32 \%\right.$ on 26 February versus $R H_{\mathrm{med}}=57 \%$ on $\left.2 \mathrm{March}\right)$. The outside climate could have influenced the effectiveness of the HPD, due to the lack of watertightness of the greenhouse. This could explain the results shown in Fig. 4. During all the efficient assays, the average value of the $T$ outside the greenhouse was higher than $15.0{ }^{\circ} \mathrm{C}$ and the average value of the $R H$ was lower than $72 \%$.

$T_{c}$ values below $0{ }^{\circ} \mathrm{C}$ decrease the vapour condensed flow $\left(V C F, \mathrm{~g} \mathrm{~h}^{-1} \mathrm{~m}^{-2} ;\right.$ Fig. $7 \mathrm{a}$ and $\left.7 \mathrm{c}\right)$. On 25 February and March 2, $R H$ began to descend approximately 20.0 min after the start of the test. However, on February $25 R H$ increased significantly during the first two defrosting due his higher duration. The $T_{c}$ values was below $0{ }^{\circ} \mathrm{C}$ for most of the assay. However, on March 2 the $R H$ values decreased from 100 to $75 \%$, with an approximately constant variation in time. The values of $V C F$, the power unit consumption $\left(P U C, \mathrm{~W} \mathrm{~m}{ }^{-2}\right)$, the unitary latent heat $\left(-q_{1}, \mathrm{~W} \mathrm{~m}^{-2}\right)$ and the coefficient of performance $(C O P)$ were lower when $T_{\mathrm{c}}$ was below $0.0^{\circ} \mathrm{C}$, probably due to a reduction in $A F T$ under such conditions. In addition, $T_{\mathrm{c}}$ values lower than $0.0^{\circ} \mathrm{C}$ forced the disconnection time of the HPD, for defrosting, to be lengthened. On the other hand, at lower values of $T$, less air capacity to retain moisture and less work requires extracting water vapor from the air [21]. In general, the operating parameters of the HPD had higher values when the values of $T$ increased and those of $R H$ decreased. The evolution of $P U C$ was upward throughout the experiment. Under these conditions, $V C F$ increased at a higher rate than $P U C$. 


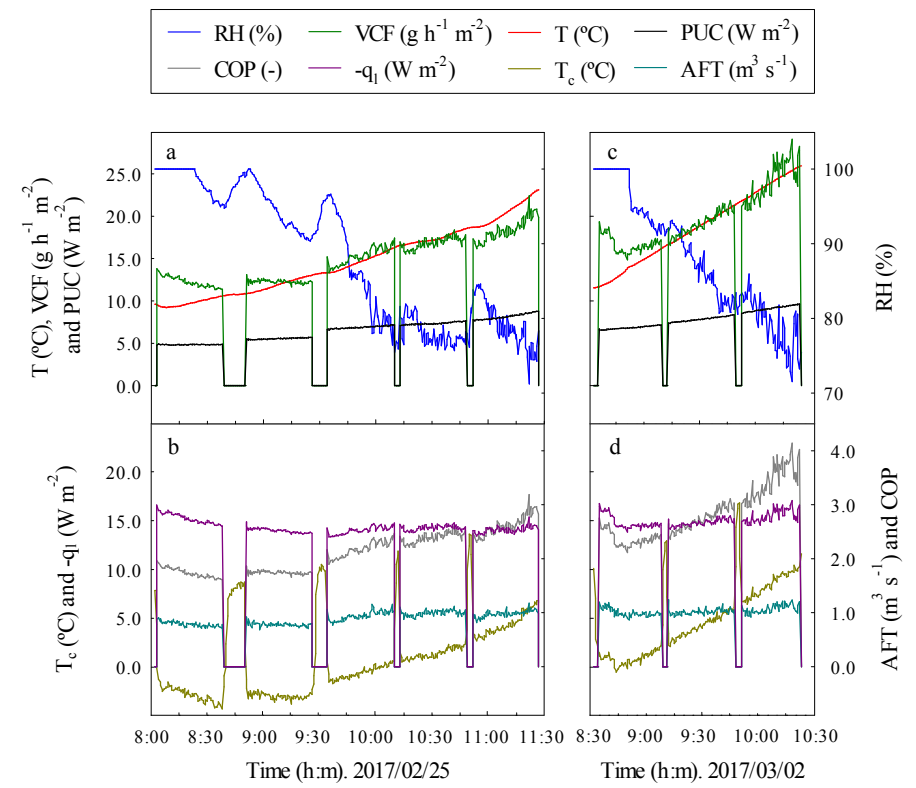

Fig. 7. Values of the HPD operating parameters in the assays of 25 February ( $a$ and b) and 2 March, 2017 ( $c$ and d) The efficacy of the HPD changes with the climatic conditions. When the weather is cold and dry, the value of $T_{c}$ decrease and HPD is not efficient. When the weather is cold and humid, the efficiency improves, but the effect of HPD on the reduction of the VPD could be insufficient. Other researchers [21] have found similar results. Dehumidification using HPD allows the recovery of the latent heat of the condensed water vapour. Therefore, the proper functioning of the HPD can increase the $T$ and, consequently, improve its efficiency. This may explain that the operation of the HPD during a sufficient time interval is efficient, even in conditions of could and dry weather (Table 1).

The maximum value of $V C F$ was $29 \mathrm{~g} \mathrm{~h}^{-1} \mathrm{~m}^{-2}$, which was reached with a $P U C$ of $9.5 \mathrm{~W} \mathrm{~m}^{-2}$ when $T$ was $25.3{ }^{\circ} \mathrm{C}$ and $R H$ was $72 \%$. Chantoiseau et al. [14] obtained a $V C F$ of $19 \mathrm{~g} \mathrm{~h}^{-1} \mathrm{~m}^{-2}$ with a power consumption of $3.2 \mathrm{~W} \mathrm{~m}^{-2}$ at $16{ }^{\circ} \mathrm{C}$ and $84 \% R H$, with an HPD in a greenhouse located in the Northwest of France. Our work yielded similar values. The difference in the value of $P U C$ in the two works is due to the differing areas covered by the greenhouses. The mean value of $P$ in our experiments was $6.3 \mathrm{~kW}$, much lower than the value of $10.23 \mathrm{~kW}$ recorded by Chantoiseau et al. [14]. In our work, the value of the global COP values varied between 2.4 and 3.1. These results indicate an efficient operation of the HPD, among other reasons, due to the use of a compressor of high energy efficiency, namely the Scroll type [29]. 


\subsection{Efficiency improvement}

The optimisation of the dehumidification system implies elimination of the risk of humidity damage ( $V P D \geq 0.20 \mathrm{kPa}$ ) together with the proper operation and minimum energy consumption, assuming $T_{\mathrm{c}} \geq 0{ }^{\circ} \mathrm{C}$. To determine the optimal performance of the HPD, the values of $V P D$ were related with $T_{\mathrm{c}}, T$, and $P$. The values of $V P D$ during the experiences varied between 0.0 and 1.5 $\mathrm{kPa}$. The values of $T$ ranged between 9.4 and $30.2{ }^{\circ} \mathrm{C}$ and those of $T_{\mathrm{c}}-9.2$ and $19.6{ }^{\circ} \mathrm{C}$. Finally, the values of $P$ varied between 5.0 and $9.8 \mathrm{~kW}$.

Fig. 8 shows the results of the quadratic relationship that provides $V P D$ from $T$ (when it varies between 10.0 and $25.0{ }^{\circ} \mathrm{C}$ ), $T_{c}$ (between -5.0 and $10.0{ }^{\circ} \mathrm{C}$ ) and $P$ (from 5.5 to $9.0 \mathrm{~kW}$ ) in function of the $R H$. In all three cases $\left(T, T_{c}\right.$ and $\left.P\right)$, the relationship of the VPD values obtained from the quadratic model $(y)$ with the experimental results $(x)$ were highly significant $(y=1.01 x$; $\left.\mathrm{R}^{2}=0.99^{* * *}\right)$.

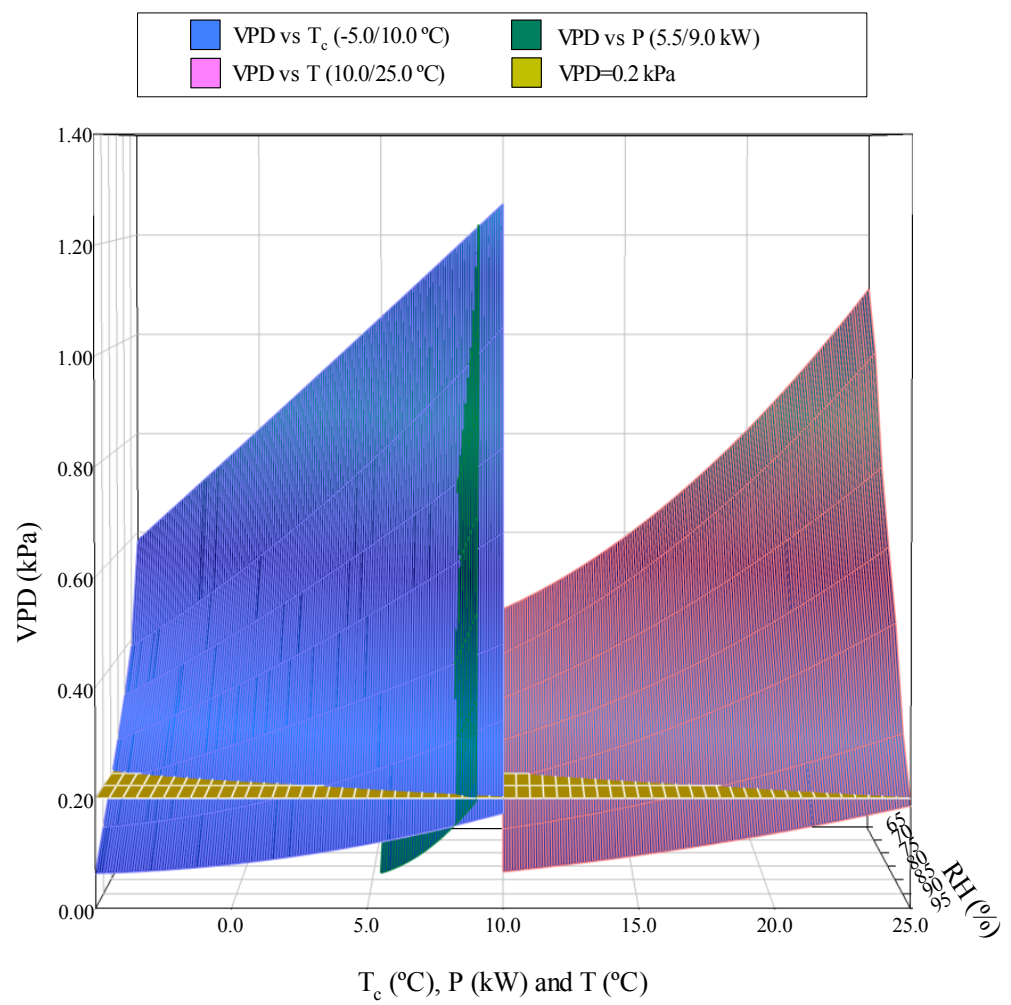

Fig. 8. Results of quadratic relationship from the $V P D(\mathrm{kPa})$ with $T_{c}\left({ }^{\circ} \mathrm{C}\right), \mathrm{P}(\mathrm{kW})$ and $\mathrm{T}\left({ }^{\circ} \mathrm{C}\right)$ according to the $R H$ (\%)

In our conditions, for values of the $T$ between 10.0 and $25.0{ }^{\circ} \mathrm{C}$, when the $R H$ is greater than 94 $\%$ is not possible to avoid the risk of damage by humidity. However, between these values of 
the $T$, there is no risk of damage by moisture if the $H R$ is lower than $84 \%$. When $R H$ ranged between 84 and $88 \%$, a value of $0.20 \mathrm{kPa}$ was achieved at $T_{c} \geq 0.0{ }^{\circ} \mathrm{C}$ if $T=15.0{ }^{\circ} \mathrm{C}$, been $P=6.5$ $\mathrm{kW}$. When $R H$ was $89 \%$, the values were $T=16.0^{\circ} \mathrm{C}, T_{c}=1.0^{\circ} \mathrm{C}$, and $P=6.8 \mathrm{~kW}$ to avoid risk of moisture damage. If $\mathrm{RH}$ was $90 \%$, the values were $T=18.0^{\circ} \mathrm{C}, T_{c}=3.0^{\circ} \mathrm{C}$, and $P=7.1 \mathrm{~kW}$. Above this value of $R H$, the values of $T$ necessary to avoid the risk of humidity damage are hardly feasible in our experimental conditions. When $R H$ varies between 84 and $88 \%$ and $T=15.0^{\circ} \mathrm{C}$, the experimental results were $C S P=13.8 \mathrm{~kg} \mathrm{~h}^{-1}$, specific moisture extraction rate $(S M E R)$ is $2.3 \mathrm{~kg}\left(\mathrm{~kW} \mathrm{~h}^{-1}\right)$ and $C O P=2.5$.

The SMER values ranged from 2.0 to 3.1 , with an average of $2.4 \mathrm{~kg}(\mathrm{~kW} \mathrm{~h})^{-1}$. These are typical values for HPDs and others novel and efficient techniques, like the combined use of a dessicant wheel with HPD [30]. The value of SMER tended to increase with the value of $T_{\mathrm{c}}$ (Fig. 9a). This relationship can be explained by considering the larger increase in $V C F$ relative to $P U C$ when $T_{\mathrm{c}}$ increases (Fig. 9b).

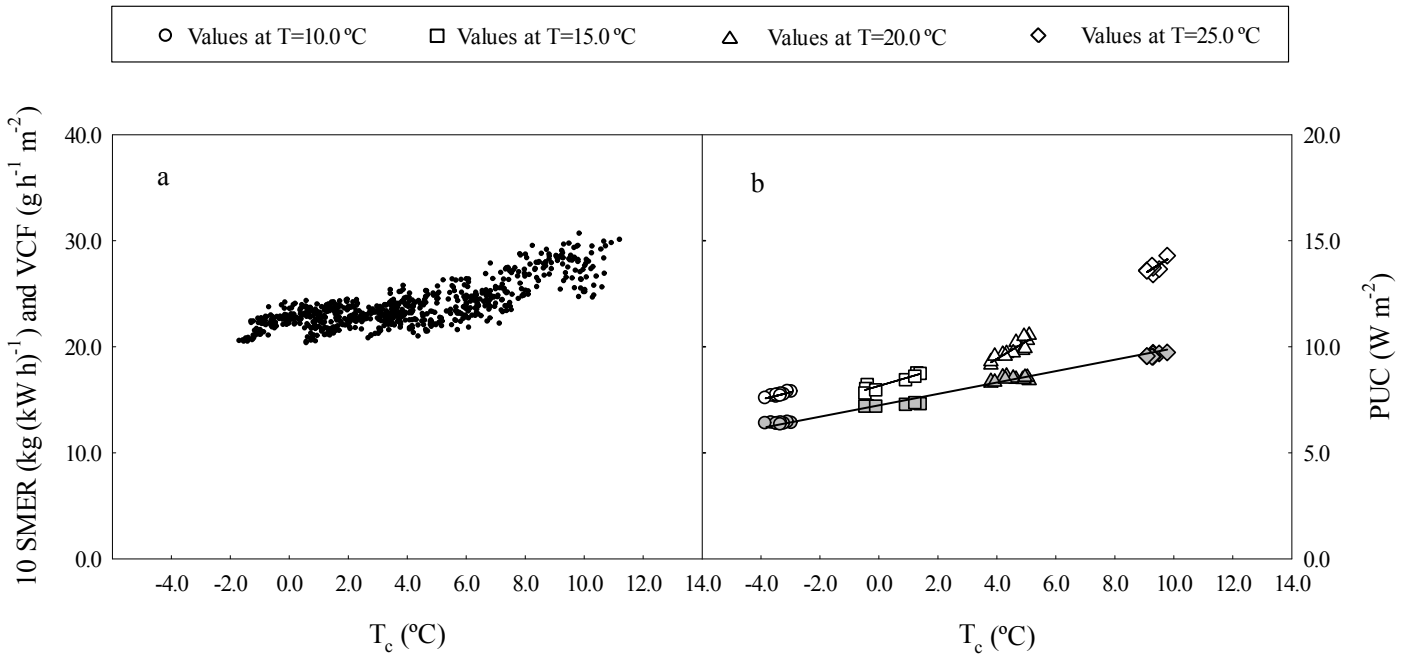

Fig. 9. a: Relationship between the values of $T_{c}\left({ }^{\circ} \mathrm{C}\right)$ and SMER $\left(\mathrm{kg}(\mathrm{kW} \mathrm{h})^{-1}\right) ; b$ : Relationship between the vapor condensed flow, VCF $\left(\mathrm{g} \mathrm{h}^{-1} \mathrm{~m}^{-2}\right)$ (main axis, in white) and the power unit consumption, PUC $\left(W \mathrm{~m}^{-2}\right)$ (secondary axis, in gray), as a function of $T_{c}\left({ }^{\circ} \mathrm{C}\right)$ for different values of the $T$.

When $T$ is constant, there is a linear relationship between $V C F$ and $T_{c}$ highly significant (Fig. 9b). When increasing the value of $T$, the slope increases and the ordinate at the origin decreases (Table 3). This indicates that the liquid water production of the HPD increases with the $T_{c}$ value. The increase in the value of $V C F$ is greater when $T$ varies between 15.0 and $20.0{ }^{\circ} \mathrm{C}$. However, the $P U C$ increases with the value of $T_{c}$ directly proportional to the increase in the value of $T$. To 
ensure a $T_{c}$ value close to $0.0^{\circ} \mathrm{C}$, the value of $T$ must be $15.0^{\circ} \mathrm{C}$ and the $R H$ between 84 and 88 $\%$. Under these conditions, the mean values of $V C F$ and $P U C$ are $16.3 \mathrm{~g} \mathrm{~h}^{-1} \mathrm{~m}^{-2}$ and $7.0 \mathrm{~W} \mathrm{~m}^{-2}$, respectively.

\begin{tabular}{|c|c|c|c|c|}
\hline $\mathrm{N}(-)$ & $T\left({ }^{\circ} \mathrm{C}\right)$ & ${\mathrm{A}\left(\mathrm{g} \mathrm{h}^{-1} \mathrm{~m}^{-2}{ }^{\circ} \mathrm{C}^{-1}\right)} \mathrm{B}\left(\mathrm{g} \mathrm{h}^{-1} \mathrm{~m}^{-2}\right)$ & $\mathrm{R}^{2}(-)$ \\
\hline 8 & 10.0 & 0.68 & 17.8 & $0.796^{* * *}$ \\
11 & 15.0 & 0.81 & 16.3 & $0.885^{* * *}$ \\
8 & 20.0 & 1.65 & 12.3 & $0.793^{* * *}$ \\
13 & 25.0 & 1.76 & 11.1 & $0.573 \mathrm{~ns}$ \\
\hline
\end{tabular}

Table 3. Values of the slope (A), the ordinate at the origin $(B)$, and the coefficient of determination $\left(R^{2}\right)$ of the linear relationship between the $\operatorname{VCF}\left(\mathrm{g} \mathrm{h}^{-1} \mathrm{~m}^{-2}\right)$ and the $T_{c}\left({ }^{\circ} \mathrm{C}\right)$ as a function of $T\left({ }^{\circ} \mathrm{C}\right) . N$ is the number of values; ${ }^{* * *}$ means $P$-values $<0.001$; ns means P-values $>0.05$.

The linear relationship between $T, T_{c}$ and $P$ when the $R H$ varies between 84 and $88 \%$ is shown in Fig. 10. The relationship between $P$ and $T$ is $P=0.2 T+3.5 ; \mathrm{R}^{2}=0.97^{* * *}$. The relation between $P$ and $T_{c}$ is $P=0.2 T_{c}+6.5 ; \mathrm{R}^{2}=0.96^{* * *}$. Finally, the relationship between $T$ and $T_{c}$ is $T=T_{c}+15.0$; $\mathrm{R}^{2}=0.98^{* * *}$. Therefore, $T=15.0{ }^{\circ} \mathrm{C}$ it could be adopted as a set value of $T$ for optimum performance.

When $T_{c}$ is equal to zero, the value of $V C F$ decreases with increasing the value of $T$ (Table 3 ). Fig. 11 shows the results of the linear relationships between the values of $T_{c}\left({ }^{\circ} \mathrm{C}\right.$ ) (between -5.0 and $10.0^{\circ} \mathrm{C}$ ) and $P$ (between 5.5 and $9.0 \mathrm{~kW}$ ) with $T$ (between 10.0 and $25.0{ }^{\circ} \mathrm{C}$ ) in function of $R H$. The linear relationships between the values shown in Fig. 11 and the experimental values are highly significant (data not shown). The value of $T_{c}$ decreases with the value of $T$ and of the $R H$. This indicates a malfunction of HPD in cold and dry climates. The development of HPD improves with increasing $T$ and $R H$. These results can be explained by the different value of the specific heat of water vapor and air. The air with higher humidity has a higher heat capacity and experiences less $T$ decrease as it passes through the evaporator ( $T_{c}$ is greater). However, air with lower humidity experiences greater $T$ decrease in the evaporator ( $T_{c}$ is smaller). These results support those found in section 3.3. Other authors conclude that the HPD is least efficient in low $T$ and high humidity climates, improving his performance as the conditions approach those of a hot and dry climate [21]. 


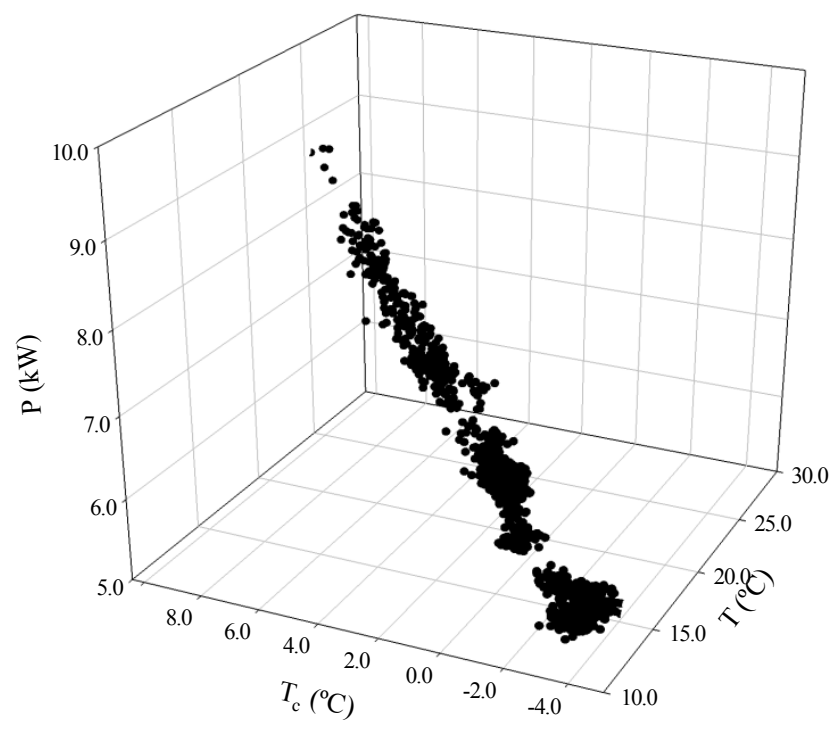

Fig. 10. Relationship between the $T\left({ }^{\circ} \mathrm{C}\right), T_{c}\left({ }^{\circ} \mathrm{C}\right)$ and $\mathrm{P}(\mathrm{kW})$ when $R H$ varies between 84 and $88 \%$.

A dry climate is not probable in a greenhouse due to the transpiration of the crop and the lack of ventilation. Therefore, it is possible to reduce the risk of moisture damage in greenhouse crops by using an HPD with optimal performance. In greenhouses located in areas with cold and dry weather, lack of tightness can reduce the efficiency of HPD. The results of using HPD should improve if the greenhouse is closed and infiltrations are reduced.

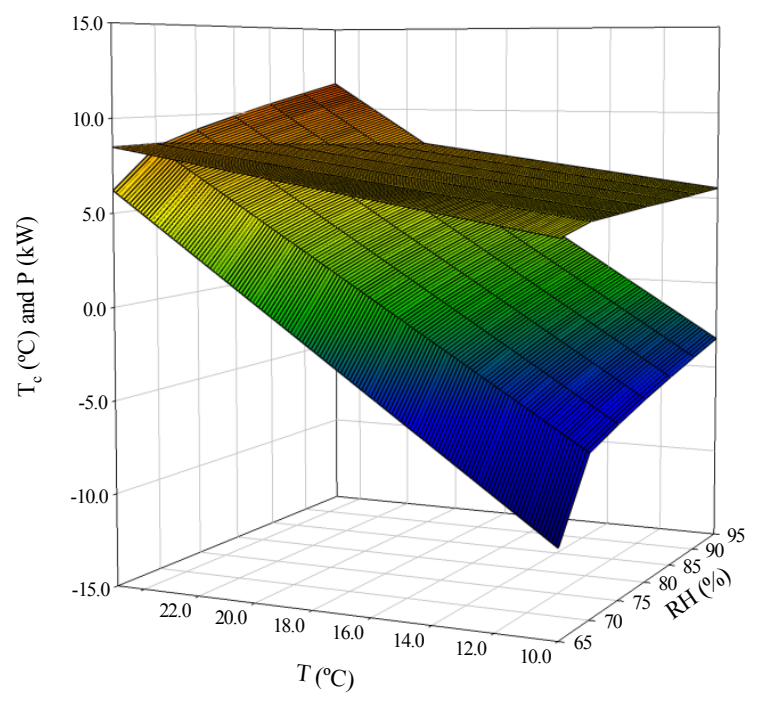

Fig. 11. Linear relationship between the values of $T_{c}\left({ }^{\circ} \mathrm{C}\right)$ (between -5.0 and $10.0{ }^{\circ} \mathrm{C}$ ) and $P$ (between 5.5 and $9.0 \mathrm{~kW}$ ) with $T$ (between 10.0 and $25.0^{\circ} \mathrm{C}$ ) in function of $\mathrm{RH}$. 
The condensation of the water vapour contained in a sample of air on a surface in contact with it depends not only on the air properties - such as $T, R H$ or $V P D$, among others - but also on the $T$ of the surface. For example, if the $T$ of the top or side roof of a greenhouse is lower than the dewpoint of the indoor air, condensation of water vapour occurs on the inner surface of said roof. Therefore, the use of these results for the control of the humidity is compatible with the existence of condensation of water vapour. The implementation of these recommendations could make the use of HPD, to reduce the risk of humidity damage, compatible with profitable production in mild weather greenhouses.

\section{Conclusions}

This work has analysed the operation of a drying heat pump (HPD) in a tomato crop in a greenhouse with conditions typical of mild weather areas. The use of the HPD can reduce the risk of humidity damage. The efficiency of the HPD was related to the value of the humidity and temperature of the air inside the greenhouse. The external climate influenced the effect of the dehumidification inside the greenhouse, probably due to its lack of watertightness. Hence, under our conditions, it is possible to eliminate the risk of humidity damage, with optimal operation of an HPD, when the condensation temperature of the water vapour is higher than 0.0 ${ }^{\circ} \mathrm{C}$, the relative humidity inside the greenhouse varies between $84 \%$ and $88 \%$, and the air temperature is at least $15^{\circ} \mathrm{C}$. In these conditions, the value of the condensed steam production is

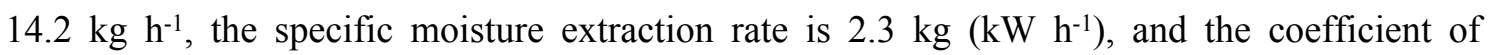
performance is 2.5. When the weather is colder and drier, the HPD is not efficient. If the weather is cold and humid, the efficiency improves, but the effect of HPD on the reduction of the risk of moisture damage could be insufficient.

Reducing the risk of moisture damage is a relatively new application of HPD. It is a technology that allows greenhouse cultivation with less use of fungicides. In case of carbon fertilization, HPD helps improve the results, reducing the need for ventilation, with the consequent beneficial effect on crop production and quality. Currently there are specialized companies marketing this 
type of facility in mild weather areas. It is necessary to continue studying the operation of HPD to determine its energy consumption throughout the crop season, as well as its effect on the use of fungicides, production and crop quality, in order to evaluate its technical-economic viability. 


\section{Funding}

This research was funded by the Controlcrop Project, P10-TEP-6174, project framework, supported by the Andalusian Ministry of Economy, Innovation and Science (Andalusia, Spain), and by the Spanish Ministry of Science and Innovation, as well as EUERDF funds under grant DPI2014-55932-C2-1-R. 


\section{Abbreviations}

RH : Relative humidity

$T \quad$ : Temperature

$V P D \quad:$ Vapour pressure deficit

$\omega \quad:$ Specific humidity

$h \quad$ : Enthalpy

$c \quad$ : Specific heat

$L \quad$ : Latent heat

$W \quad$ : Mechanical energy transfer

$P \quad$ : Power

$P U C \quad$ : Power per unit of area

$Q \quad$ : Heat transfer

$q \quad:$ Heat transfer per unit of time and area

$S H F \quad:$ Sensible heat factor

$M C V$ : Mass of condensed water vapour

$V C F$ : Vapour condensed flow

CSP : Condensed steam production

$M A T$ : Mass of air treated in the heat pump dehumidifier

$A F T$ : Air flow treated in the heat pump dehumidifier

$S M E R$ : Specific moisture extraction rate

$C O P$ : Coefficient of performance

he : Heating energy per unit of area

$w \quad$ : Energy per unit of area due to dehumidifier

$m \quad$ : Mass

tr : :Transpiration

E $\quad:$ Energy of air

$\omega \quad:$ Specific humidity

\section{Subscript}

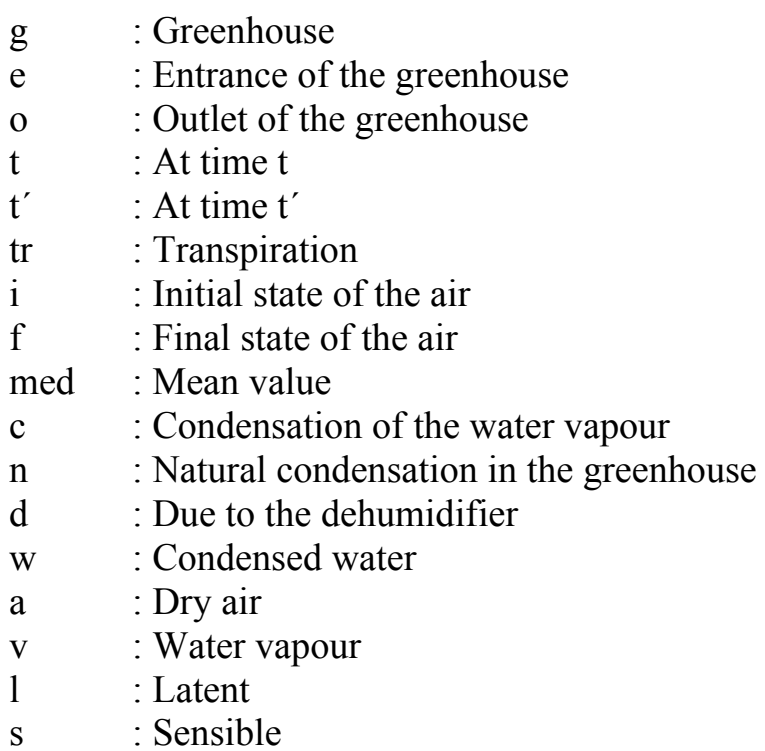




\section{Appendix}

Determination of the mass of condensed water vapour in the desiccator, $M C V(\mathrm{~kg})$, over a period of time $\Delta t(\mathrm{~s})$.

An amount of air mass is analyzed that at time $t(\mathrm{~s})$ is inside the greenhouse and in an adjacent region called entrance. At time $t^{\prime}=t+\Delta t(\mathrm{~s})$, the mass of dry air analyzed is located in the greenhouse and in a different area called outlet. The mass balance for the dry air is given as:

$$
m_{\mathrm{g}, \mathrm{t}}+m_{\mathrm{a}_{\mathrm{e}}}=m_{\mathrm{a}_{\mathrm{g}, \mathrm{t}}}+m_{\mathrm{a}_{\mathrm{o}}}(1)
$$

For the water vapour it is necessary to consider two additional transfers, transpiration and natural condensation inside the greenhouse:

$$
m_{\mathrm{v}_{\mathrm{g}, \mathrm{t}}}+m_{\mathrm{v}_{\mathrm{e}}}+m_{\mathrm{v}_{\mathrm{tr}}}=m_{\mathrm{v}_{\mathrm{g}, \mathrm{t}}}+m_{\mathrm{v}_{\mathrm{o}}}+m_{\mathrm{w}, \mathrm{n}}(2)
$$

Where $m_{\mathrm{v}_{\mathrm{tr}}}(\mathrm{kg})$ represents the mass of water vapour incorporated into greenhouse air in the time interval $\Delta t$ (s) due to transpiration (it can be zero or positive). In turn, $m_{\mathrm{w}, \mathrm{n}}(\mathrm{kg})$ represents the mass of water vapour that naturally condenses in this interval (it can be negative, zero, or positive). Unknown variables can be related by simple expressions, such as $\omega \mathrm{e}=m_{\mathrm{v}_{\mathrm{e}}} / \mathrm{ma}_{\mathrm{e}}\left(\mathrm{kg}_{\mathrm{v}}\right.$ $\left.\mathrm{kga}^{-1}\right)$ or $\omega_{0}=m_{v_{0}} / m_{a_{0}}\left(\mathrm{~kg}_{v} k g a^{-1}\right)$.

The energy balance of the greenhouse air can be determined considering that, initially, $E_{\mathrm{t}}=m_{\mathrm{ag}, \mathrm{t}}$ $h_{\mathrm{g}, \mathrm{t}}+m_{\mathrm{a}} h_{\mathrm{e}}+m_{\mathrm{v}_{\text {tr }}} h_{\mathrm{w}_{\text {tr }}}(\mathrm{J})$, where $\left(m_{\mathrm{v}_{\mathrm{tr}}} h_{\mathrm{w}_{\mathrm{tr}}}\right)$ represents the energy incorporated into the air as a consequence of transpiration during the time interval $\Delta t$. At time $t^{\prime}, \mathrm{E}_{\mathrm{t}^{\prime}}=m_{\mathrm{ag}, \mathrm{t}^{\prime}} h_{\mathrm{g}, \mathrm{t}^{\prime}}+m_{\mathrm{a}_{\mathrm{o}}} h_{\mathrm{o}}+m_{\mathrm{w}, \mathrm{n}}$ $h_{\mathrm{w}, \mathrm{n}}(\mathrm{J})$, where $\left(m_{\mathrm{w}, \mathrm{n}} h_{\mathrm{w}, \mathrm{n}}\right)$ represents the variation in the energy of the air due to the natural condensation inside the greenhouse during $\Delta t$. The balance of energy between $t$ y $t^{\prime}$ can be expressed as $E_{\mathrm{t}^{\prime}}-E_{\mathrm{t}}=Q-W$. In this case, $W=0$, so that:

$$
Q=m_{\mathrm{ag}, \mathrm{t}^{\prime}} h_{\mathrm{g}, \mathrm{t}^{\prime}}-m_{\mathrm{ag}, \mathrm{t}} h_{\mathrm{g}, \mathrm{t}}+m_{\mathrm{a}_{\mathrm{o}}} h_{\mathrm{o}}-m_{\mathrm{a}_{\mathrm{e}}} h_{\mathrm{e}}+m_{\mathrm{w}, \mathrm{n}} h_{\mathrm{w}, \mathrm{n}}-m_{\mathrm{v}_{\mathrm{tr}}} h_{\mathrm{w}_{\mathrm{tr}}}(3)
$$


It is convenient to express the transfer of energy in the form of heat, $Q$, as a function of the properties of the air and whose value is independent of the performance of the HPD. For this, $m_{\mathrm{w}, \mathrm{n}}$ in Eq. (2) is removed and substituted in Eq. (3), giving:

$$
Q=m_{\mathrm{ag}, \mathrm{t}^{\prime}}\left(h_{\mathrm{g}, \mathrm{t}^{\prime}}-\omega_{\mathrm{g}, \mathrm{t}^{\prime}} h_{\mathrm{w}, \mathrm{n}}\right)-m_{\mathrm{g}, \mathrm{t}}\left(h_{\mathrm{g}, \mathrm{t}^{-}}-\omega_{\mathrm{g}, \mathrm{t}} h_{\mathrm{w}, \mathrm{n}}\right)+m_{\mathrm{a}}\left(h_{\mathrm{o}}-\omega_{\mathrm{o}} h_{\mathrm{w}, \mathrm{n}}\right)-m_{\mathrm{e}}\left(h_{\mathrm{e}}-\omega_{\mathrm{e}} h_{\mathrm{w}, \mathrm{n}}\right)-m_{\mathrm{vtr}}\left(h_{\mathrm{w} \mathrm{tr}}-h_{\mathrm{w}, \mathrm{n}}\right)
$$

When the operation of the desiccator is considered, the mass balance of the dry air in the greenhouse (Eq. 1) is maintained, but that of the water vapour in the greenhouse (Eq. 2) changes because the mass of condensed water vapour in the desiccator must be considered in the time interval of operation $\Delta t\left(m_{\mathrm{w}, \mathrm{d}}\right)$, giving:

$$
m_{\mathrm{v}_{\mathrm{g}, \mathrm{t}}}+m_{\mathrm{v}_{\mathrm{e}}}+m_{\mathrm{v}_{\mathrm{tr}}}=m_{\mathrm{v}_{\mathrm{g}, \mathrm{t}}}+m_{\mathrm{v}_{\mathrm{o}}}+m_{\mathrm{w}, \mathrm{n}}+m_{\mathrm{w}, \mathrm{d}}(5)
$$

In this case, it can be considered that in a time interval, $\Delta t$, the interior air of the greenhouse exchanges $Q$ and further experiences a heat transfer in the evaporator and the condenser of the desiccator. If the vapour compression cycle of the desiccator had the characteristics of a reversible cycle, the net work would coincide with the net heat exchanged in each cyclic process. Since it is a real steam compression cycle, it is only possible to establish a relationship between the work consumed by the desiccator, $W$, and the heat exchanged by the air in the greenhouse, in each cyclic process of the desiccator. In an interval, $\Delta t$, this ratio must be maintained, so that the energy balance of the air in the greenhouse can be written as:

$$
m_{\mathrm{ag}, \mathrm{t}^{\prime}} h_{\mathrm{g}, \mathrm{t}^{\prime}}-m_{\mathrm{ag}, \mathrm{t}} h_{\mathrm{g}, \mathrm{t}}+m_{\mathrm{a}_{\mathrm{o}}} h_{\mathrm{o}}-m_{\mathrm{a}_{\mathrm{e}}} h_{\mathrm{e}}+m_{\mathrm{w}, \mathrm{n}} h_{\mathrm{w}, \mathrm{n}}+m_{\mathrm{w}, \mathrm{d}} h_{\mathrm{w}, \mathrm{d}}-m_{\mathrm{tr}} h_{\mathrm{wtr}}=Q-W(6)
$$

In our experimental conditions, it is considered that the operation of the HPD only affects the value of the mass of naturally condensed vapour $\left(m_{\mathrm{w}, \mathrm{n}}\right)$, which can be removed from Eq. (5) and inserted in Eq. (6), giving:

$$
\begin{gathered}
Q=W_{d}+m_{\mathrm{a}, \mathrm{t}^{\prime}}\left(h_{\mathrm{g}, \mathrm{t}^{\prime}}-\omega_{\mathrm{g}, \mathrm{t}^{\prime}} h_{\mathrm{w}, \mathrm{n}}\right)-m_{\mathrm{g}, \mathrm{t}}\left(h_{\mathrm{g}, \mathrm{t}^{-}} \omega_{\mathrm{g}, \mathrm{t}} h_{\mathrm{w}, \mathrm{n}}\right)+m_{\mathrm{a}}\left(h_{\mathrm{o}}-\omega_{\mathrm{o}} h_{\mathrm{w}, \mathrm{n}}\right)-m_{\mathrm{e}}\left(h_{\mathrm{e}}-\omega_{\mathrm{e}} h_{\mathrm{w}, \mathrm{n}}\right)+m_{\mathrm{w}, \mathrm{d}}\left(h_{\mathrm{w}, \mathrm{d}}-h_{\mathrm{w}, \mathrm{n}}\right)- \\
m_{\mathrm{vtr}}\left(h_{\mathrm{wtr}}-h_{\mathrm{w}, \mathrm{n}}\right)(7)
\end{gathered}
$$

Eqs. (4) and (7) allow determination of the heat transfer of the air in the greenhouse as a function of the values of the properties of the interior air and of the mass of the interior air at 
times $t$ and $t^{\prime}$, the masses of air entering and leaving the greenhouse in the interval $\Delta t$, and the transpiration. In general, the values of these quantities are independent of the operation of the desiccator whereby both expressions can be subtracted to determine $m_{\mathrm{w}, \mathrm{d}}$ :

$$
m_{\mathrm{w}, \mathrm{d}}=W_{d} /\left(h_{\mathrm{w}, \mathrm{n}}-h_{\mathrm{w}, \mathrm{d}}\right)(8)
$$

Where $W_{d}>0$ for the greenhouse air, since it is energy in the form of work transferred from the system (the enthalpy of the air circulating through the desiccator decreases). In each drying interval the mean value of the facility's performance is obtained based on the premise that the sum of all the values of $m_{\mathrm{w}, \mathrm{d}}$ determined by Eq. (8) must correspond to the total mass of liquid water obtained during said interval. 


\section{References}

[1] N. Castilla, E. Baeza, Good agricultural practices for greenhouse vegetable crops : principles for Mediterranean climate areas, in: W. Baudoin, R., Nono-Womdim, N. Lutaladio, A. Hodder (Eds.), FAO plant production and protection paper 217, Rome, 2013, pp. 21-34.

[2] F. Rodríguez, M. Berenguel, J.L. Guzmán, A. Ramírez-Arias, Modeling and control of greenhouse crop growth, Springer International Publishing Switzerland, London, 2015. doi:10.1007/978-3-319-11134-6.

[3] C. von Zabeltitz, Integrated greenhouse systems for mild climates, Springer, London, 2011.

[4] J. Pérez-Parra, A. Ramírez-Arias, M. Berenguel, F. Rodríguez, Ventilation rate models of mediterranean greenhouses for control purposes, Acta Hortic. 719 (2006) 197-204. doi:10.17660/ActaHortic.2006.719.20.

[5] D.W. Hand, Effects of atmospheric humidity on greenhouse crops, Acta Hortic. 229 (1988) 143-158. doi:10.17660/ActaHortic.1988.229.12.

[6] N. Katsoulas, A. Sapounas, F. De Zwart, J.A. Dieleman, C. Stanghellini, Reducing ventilation requirements in semi-closed greenhouses increases water use efficiency, Agr. Water Manage. 156 (2015) 90-99. doi:10.1016/j.agwat.2015.04.003.

[7] G. Zaragoza, M. Buchholz, P. Jochum, J. Pérez-Parra, Watergy project: Towards a rational use of water in greenhouse agriculture and sustainable architecture, Desalination 211 (2007) 296-303. doi:10.1016/j.desal.2006.03.599.

[8] F.J. Baptista, B.J. Bailey, J.F. Meneses, Effect of nocturnal ventilation on the occurrence of Botrytis cinerea in Mediterranean unheated tomato greenhouses, Crop Prot. 32 (2012) 144-149. doi:10.1016/j.cropro.2011.11.005.

[9] F. Baptista, Modelling the climate in unheated tomato greenhouses and predicting Botrytis cinerea infection, PhD Thesis, Universidade de Évora, Évora, 2007. 
[10] D. Piscia, J.I. Montero, E. Baeza, B.J. Bailey, A CFD greenhouse night-time condensation model, Biosyst. Eng. 111 (2012) 141-154. doi:10.1016/j.biosystemseng.2011.11.006.

[11] J.B. Campen, G.P.A. Bot, H.F. De Zwart, Dehumidification of greenhouses at northern latitudes, Biosyst. Eng. 86 (2003) 487-493. doi:10.1016/j.biosystemseng.2003.08.008.

[12] D.R. Rousse, D.Y. Martin, R. Thériault, F. Léveillée, R. Boily, Heat recovery in greenhouses: a practical solution, Appl. Therm. Eng. 20, 8 (2000) 687-706. http://doi.org/10.1016/S1359-4311(99)00048-4.

[13] M. Trigui, S.F. Barrington, L. Gauthier, Effects of humidity on tomato (Lycopersicon Esculentum cv. Truss) water uptake, yield, and dehumidification cost, Can. Agr. Eng. 41 (1999) 135-140.

[14] E. Chantoiseau, C. Migeon, G. Chasseriaux, P.E. Bournet, Heat-pump dehumidifier as an efficient device to prevent condensation in horticultural greenhouses, Biosyst. Eng. 142 (2016) 27-41. doi: 10.1016/j.biosystemseng.2015.11.011.

[15] T. Boulard, A. Baille, J. Lagier, M. Mermier, E. Vanderschmitt, Water vapour transfer in a plastic house equipped with a dehumidification heat pump, J. Agr. Eng. Res. 44 (1989) 191-204. doi:10.1016/S0021-8634(89)80081-2.

[16] J Han, Z. Gao, H. Guo, R. Brad, D. Waterer, Comparation of greenhouse dehumification strategies in cold regions, Appl. Eng. Agric. 31, 1 (2015) 133-142. doi: 10.13031/aea.31.10723.

[17] S. Adams, A. Langton, C. Plackett, Energy management in protected cropping: Humidity control. Factsheet 07/09. Department for environment food and rural affairs, Kent, 2009, pp. 1-12. http://www.growsave.co.uk/userFiles/factsheet_07_09.pdf. Accessed on $2017 / 05 / 08$.

[18] K.J. Chua, S.K. Chou, W.M. Yang, J. Yan, Achieving better energy-efficient air conditioning - A review of technologies and strategies, Appl. Energ. 104 (2013) 87-104. 
doi: 10.1016/j.apenergy.2012.10.037.

[19] W. Goetzler, R. Zogg, J. Young, C. Johnson, Alternatives to vapor-compression HVAC technology, ASHRAE 56, 10 (2014) 12-23.

[20] D.T. Bui, M.K. Ja, J.M. Gordon, K.C. Ng, K.J. Chua, A thermodynamic perspective to study energy performance of vacuum-based membrane dehumidification, Energy 132 (2017) 106-115. doi: 10.1016/j.energy.2017.05.075.

[21] O. Labban, T. Chen, A.F. Ghoniem, J.H. Lienhard, L.K. Norford, Next-generation HVAC: Prospects for and limitations of desiccant and membrane-based dehumidification and cooling, Appl. Energ. 200 (2017) 330-346. doi: 10.1016/j.apenergy.2017.05.051.

[22] G.A. Longo, A. Gasparella, Three years experimental comparative analysis of a desiccant based air conditioning system for a flower greenhouse: Assessment of different desiccants, Appl. Therm. Eng. 78 (2015) 584-590.

[23] A. Ali, K. Ishaque, A. Lashin, N. Al Arifi, Modeling of a liquid desiccant dehumidification system for close type greenhouse cultivation, Energy 118 (2017) 578-589. doi: 10.1016/j.energy.2016.10.069.

[24] A.L. Buck, New equations for computing vapor pressure and enhancement factor, J. Appl. Meteorol. 20 (1981) 1527-1532.

[25] M.J. Moran, H.N. Shapiro, D.D. Boettner, M.B. Bailey, Fundamentals of engineering thermodynamics, seventh ed., John Wiley \& Sons, Inc., New York, 2010.

[26] C.O. Perera, M.S. Rahman, Heat pump dehumidifier drying of food, Trends Food Sci. Tech. 8 (2004) 75-9.

[27] J.C. Bakker, Effect of day and night humidity on yield and fruit quality of glasshouse tomatoes (Lycopersicon esculentum Mill.), J. Hortic. Sci. 65 (1990) 323-331.

[28] L. Zang, Y. Jiang, J. Dong, Y. Yao, S. Deng, An experimental study for frost distribution 
and growth on finned tube heat exchangers used in air source heat pump units, Appl. Therm. Eng. 132 (2018) 38-51.

[29] K.J. Chua, S.K. Cho, W.M. Yang, Advances in heat pump systems: A review, Appl. Energ. 87 (2010) 3611-3624. doi: 10.1016/j.apenergy.2010.06.014.

[30] C.H. Chen, C.Y. Hsu, C.C. Chen, Y.C. Chiang, S.L. Chen, Silica gel/polymer composite desiccant wheel combined with heat pump for air-conditioning systems, Energy 94 (2016) 87-99. doi:10.1016/j.energy.2015.10.139. 


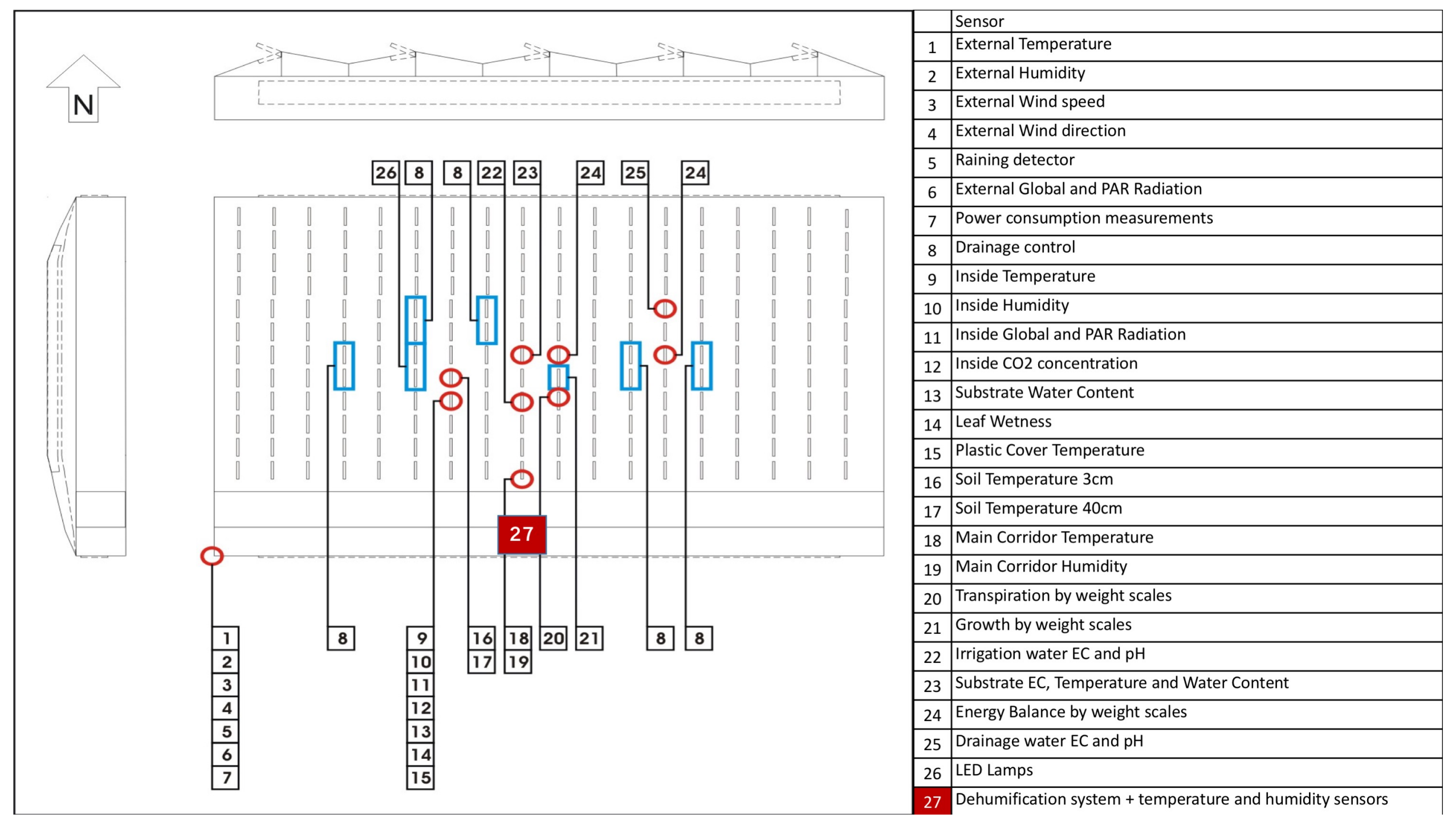




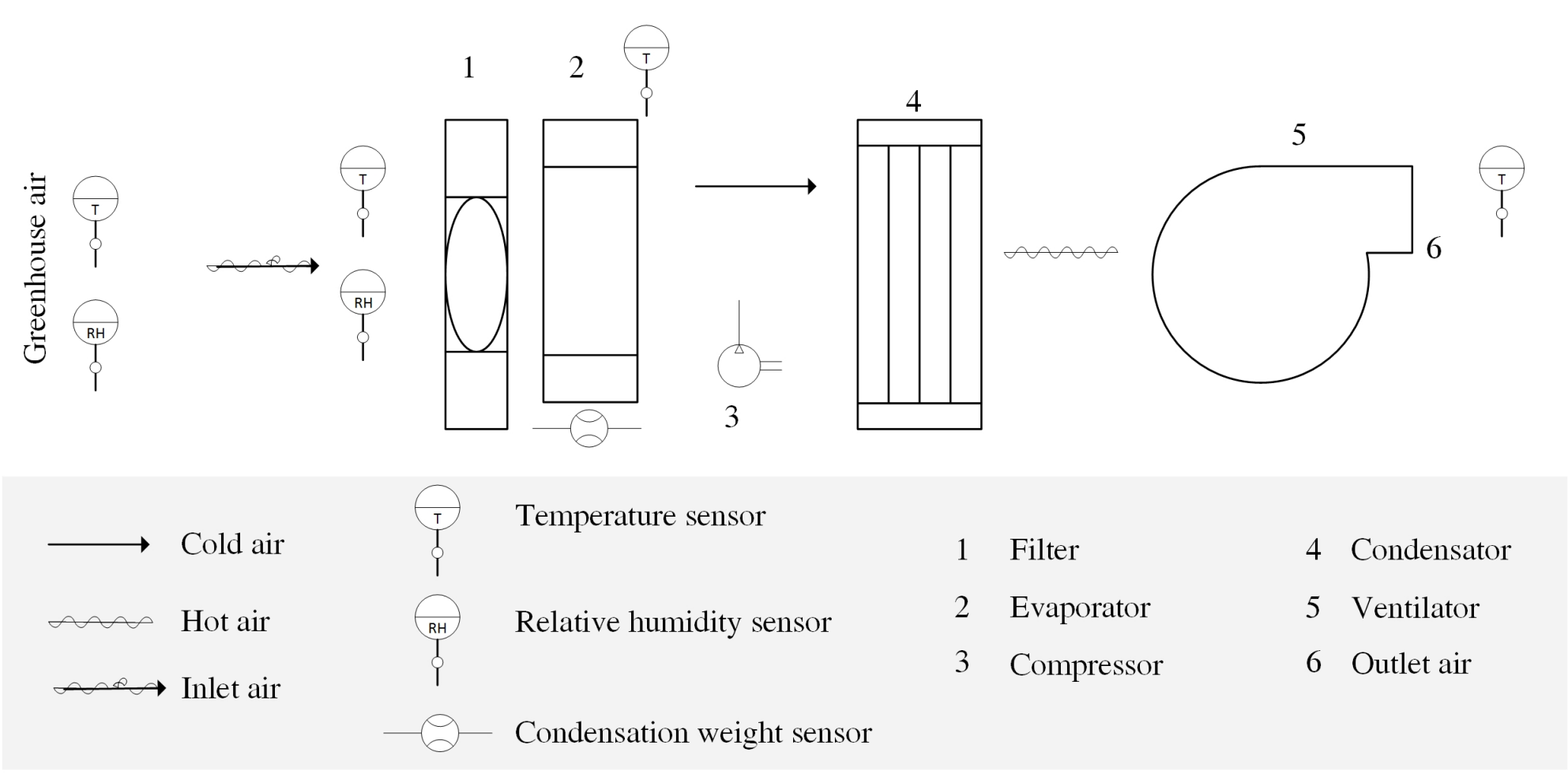




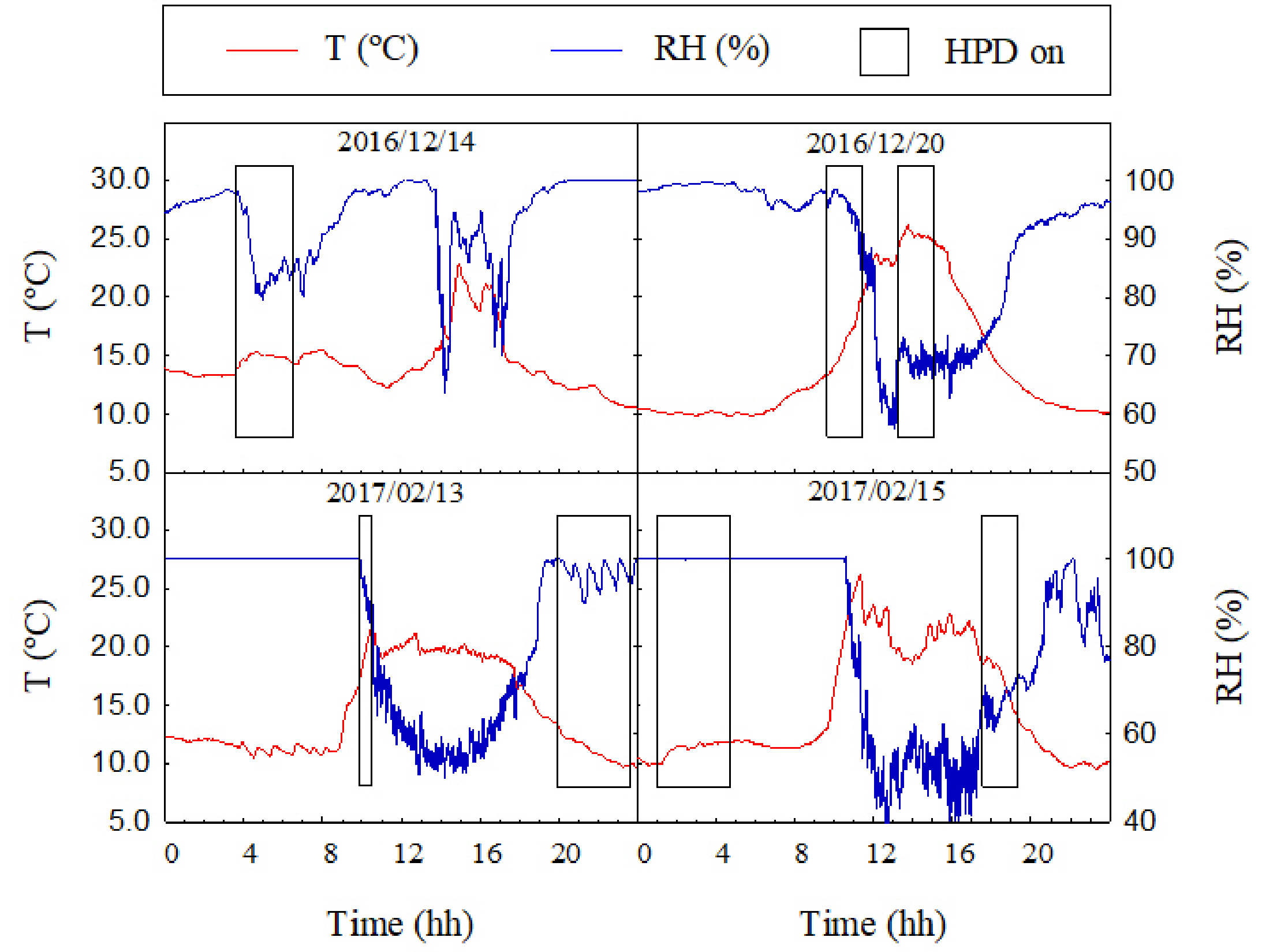




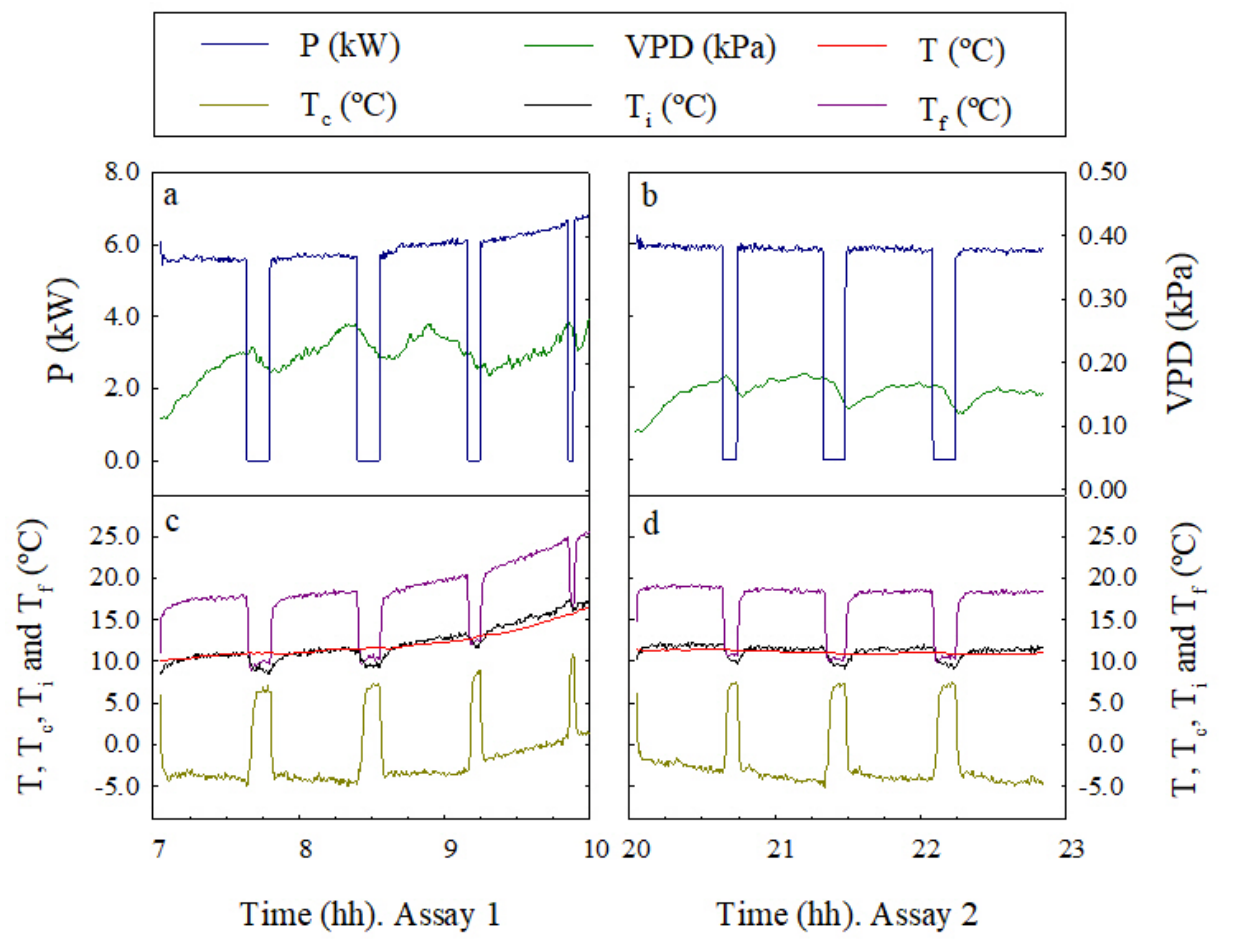




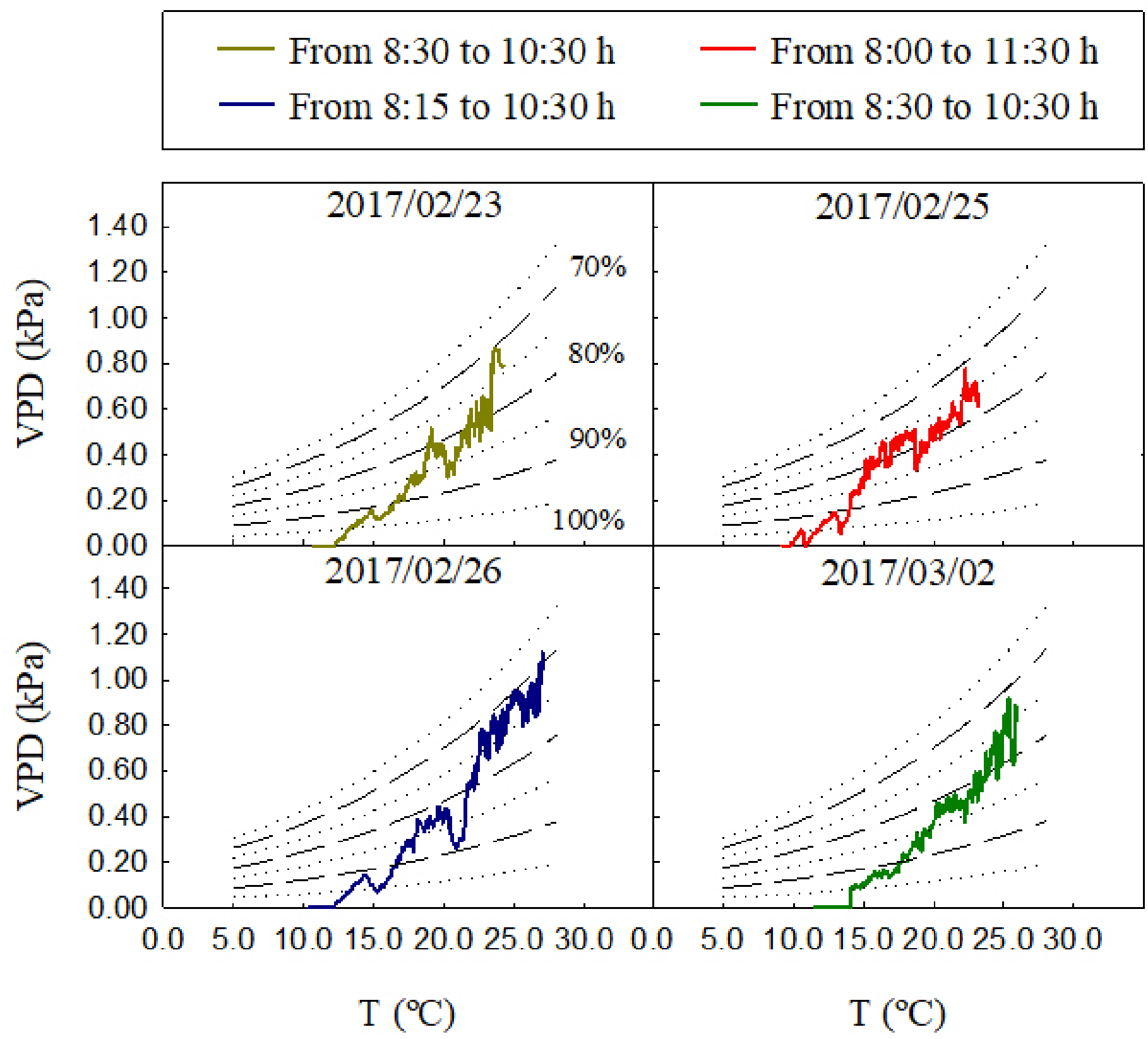




$$
\begin{aligned}
& -\mathrm{RH}(\%)-\mathrm{VCF}\left(\mathrm{g} \mathrm{h}^{-1} \mathrm{~m}^{-2}\right)-\mathrm{T}\left({ }^{\circ} \mathrm{C}\right)-\mathrm{PUC}\left(\mathrm{W} \mathrm{m}^{-2}\right) \\
& \mathrm{COP}(-)-\mathrm{q}_{1}\left(\mathrm{~W} \mathrm{~m}^{-2}\right)-\mathrm{T}_{\mathrm{c}}\left({ }^{\circ} \mathrm{C}\right)-\mathrm{AFT}\left(\mathrm{m}^{3} \mathrm{~s}^{-1}\right)
\end{aligned}
$$

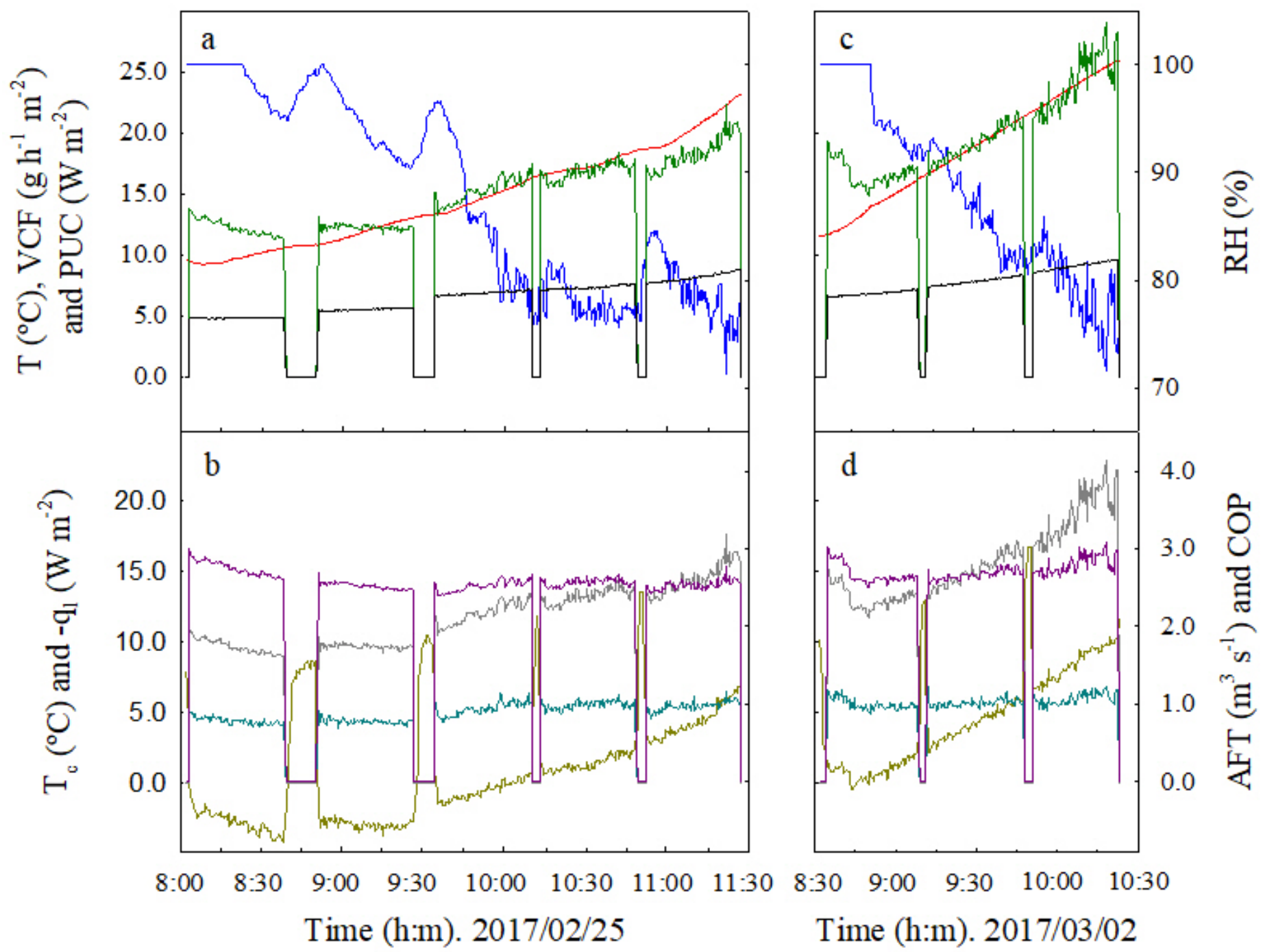




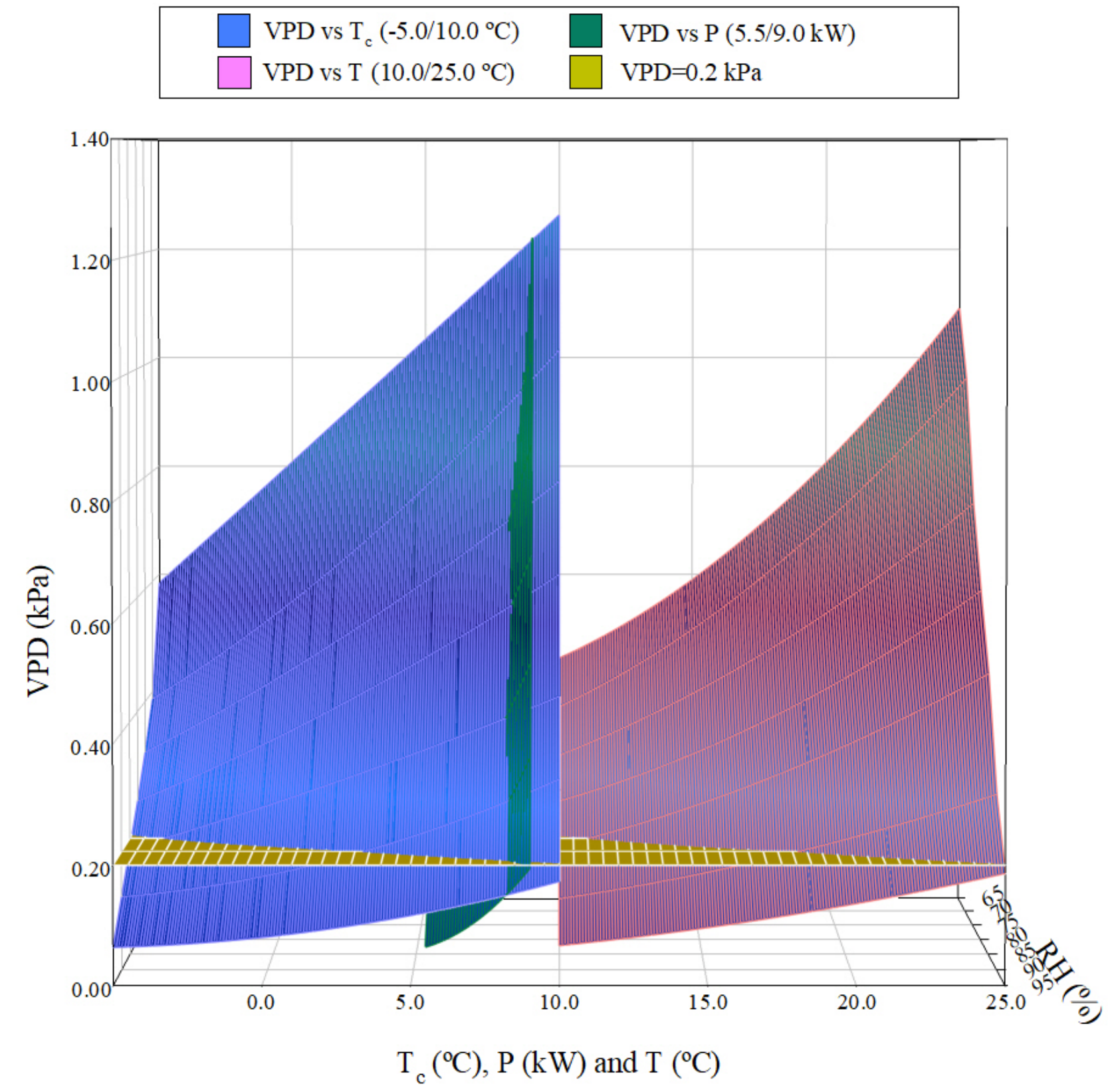




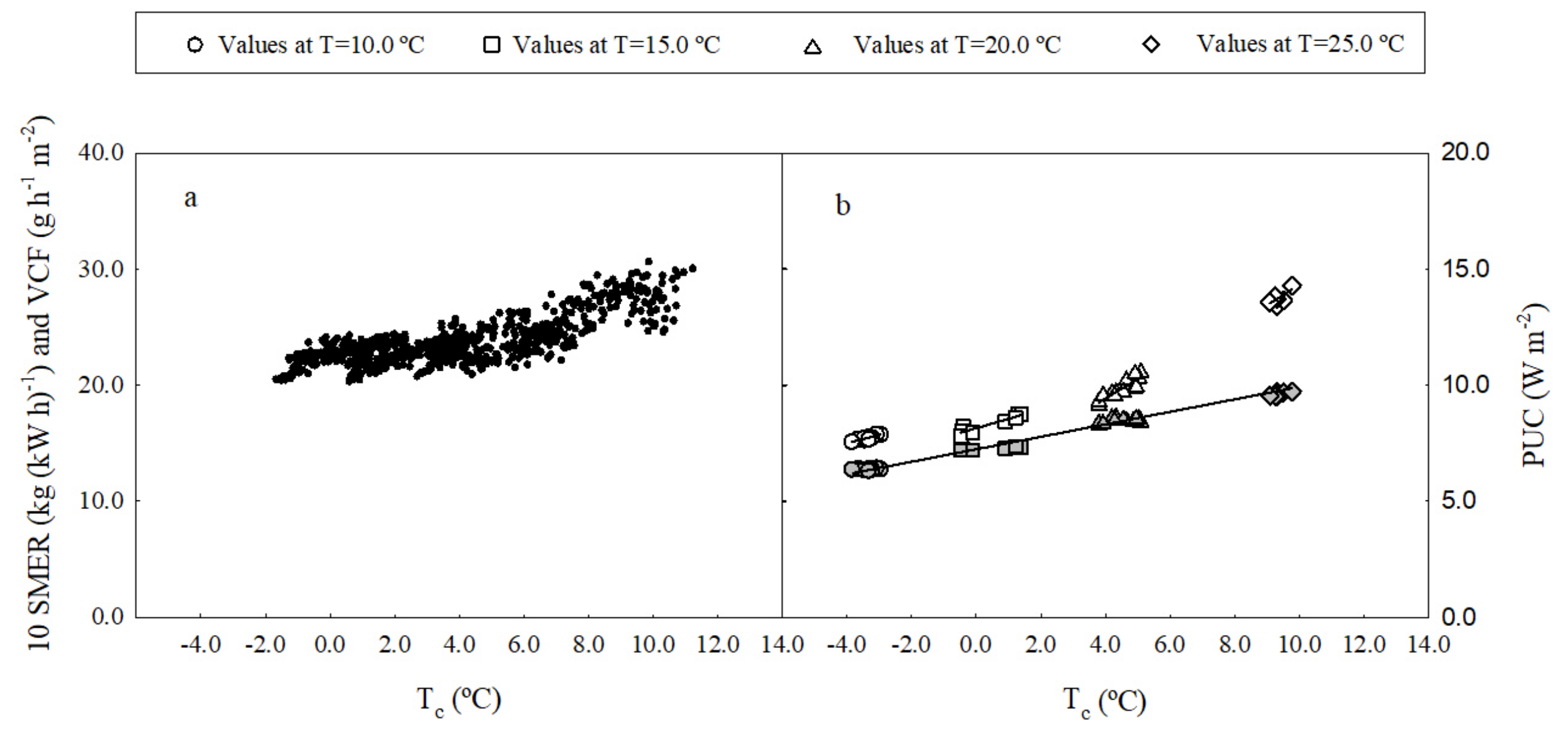




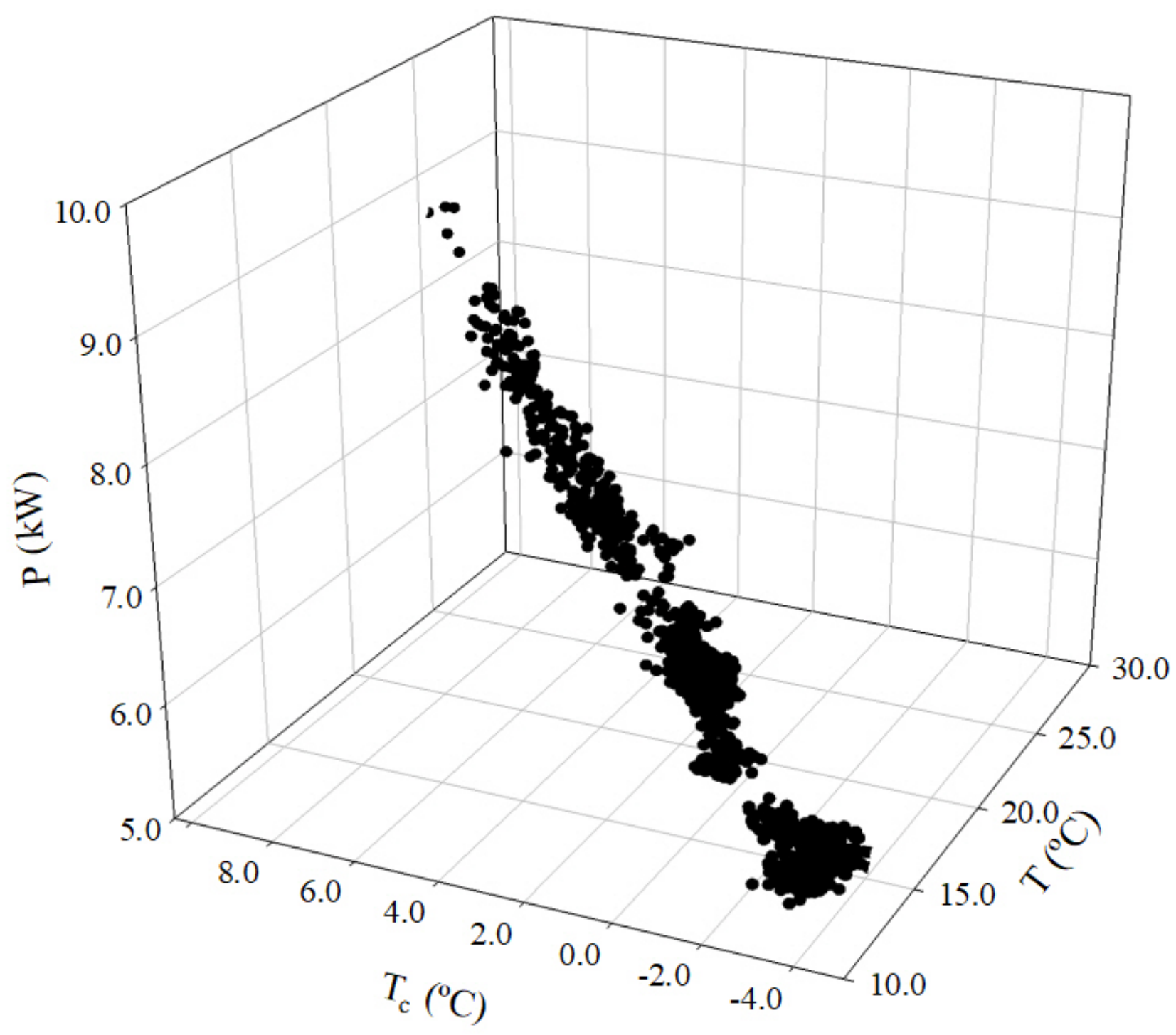




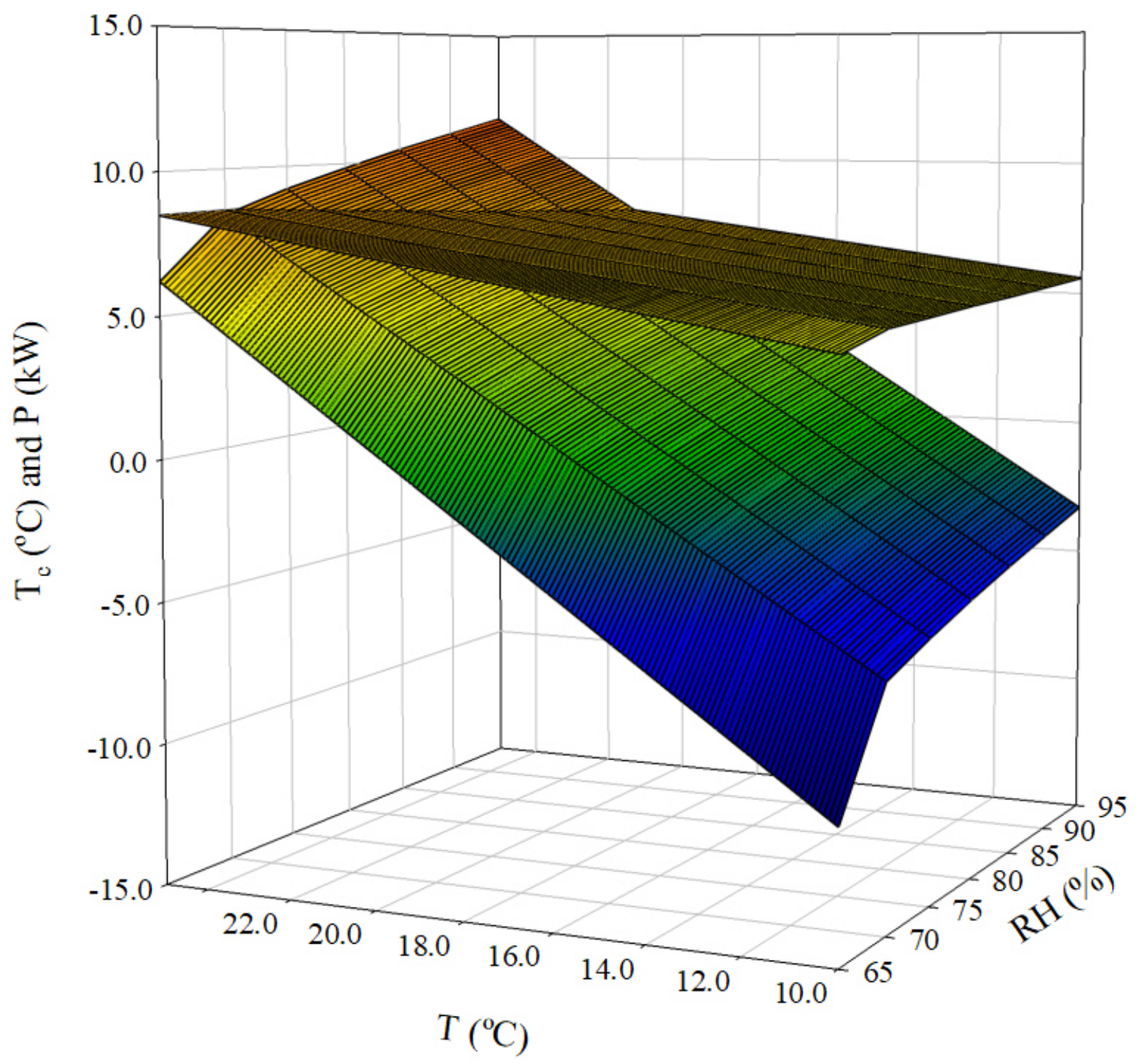

